\title{
SUPREMACIA JUDICIAL E COMPETÊNCIAS MONOCRÁTICAS: DUAS CRÍTICAS SOBRE A ATUAÇÃO DO SUPREMO TRIBUNAL FEDERAL AO LONGO DE 30 ANOS DE VIGÊNCIA DA CONSTITUIÇÃO FEDERAL DE 1988
}

\author{
JUDICIALSUPREMACY AND MONOCRATIC COMPETENCES: TWO CRITICISMS ABOUT \\ THE BRAZILIAN FEDERAL SUPREME COURT PERFORMANCE OVER THE 30-YEAR \\ PERIOD OF THE CONSTITUTION OF 1988
}

Thalles Furtado Leba

\begin{abstract}
Mestrando em Direito Público pela Universidade do Estado do Rio de Janeiro (2017-atual). Advogado.
\end{abstract} E-mail: thallesleba@gmail.com

Recebido em: 11/09/2018

Aprovado em: 28/04/2019

RESUMO: o presente trabalho visa a analisar criticamente dois fenômenos atinentes ao exercício da jurisdição constitucional no Brasil, após o advento da Constituição Federal de 1988. Em primeiro lugar, se ocupa da noção de Supremacia Judicial e como, na prática, essa ideia pode ser suplantada por uma relação dialógica entre os Poderes. Em segundo lugar, o trabalho esmiuçará a questão do uso excessivo de competências monocráticas da mais alta Corte do país e como esse fator pode causar problemas jurídicos, democráticos e institucionais. A tese adotada é de que o Supremo Tribunal Federal não pode empreender atuações excessivamente individualistas, uma vez que pode ver reduzida a sua legitimidade institucional. Ao final de cada seção, o trabalho tentará propor soluções para eventuais problemas diagnosticados.

Palavras-chave: Supremo Tribunal Federal. Supremacia Judicial. Diálogos Constitucionais. Competências Monocráticas. Capacidades Institucionais. Deliberação. Democracia.

\begin{abstract}
: the present paper sought to analyses critically two phenomena's linked with the constitutional jurisdiction in Brazil, after the enactment of the Constitution of 1988. Firstly, we focus on the Judicial supremacy approach and how, in the praxis, this idea could be overreached by a dialogic relationship with the other branches. Secondly, this work will show the issue of excessive usage of monocratic competences and how it could bring serious juridical, democratic and institutional injuries. The following assumption is that the Brazilian Federal Supreme Court could not work in a high-degree individualistic position, as it can face a reduction in its institutional legitimacy.In the end of each section, this paper will try to propose solutions for eventual diagnosed problems.
\end{abstract}

Key-words:Brazilian Federal Supreme Court. Judicial Supremacy. Constitucional dialogues. Monocratic Competences. Institucional Capacities. Deliberation. Democracy.

SUMÁRIO: Introdução; 1. Da supremacia Judicial à Doutrina dos diálogos constitucionais; 1.1. condições para a ascensão e expansão do Supremo Tribunal Federal; Que Supremacia? Breves notas sobre as experiências norte americana e brasileira; 1.3. A doutrina dos diálogos constitucionais; 2. O Supremo e as competências monocráticas; 2.1. Breve análise das 
competências do Supremo Tribunal Federal: competências superlativas?; 2.2. Distorções democráticas e representativas?; 2.3. As "onze ilhas" e a insegurança jurídica; 2.4. Proposições; Conclusão; Referências Bibliográficas.

\section{INTRODUÇÃO}

Com o advento da Constituição Federal de 1988, a ideia de Supremacia Judicial, no contexto da separação e interação entre os Poderes, foi diversas vezes enunciada quase como um axioma. E isso porque,com a nova ordem jurídica promulgada,o Poder Judiciário foi alçado a uma posição de destaque, especialmente em razão das garantias da Magistratura, que lhe garantiu a possibilidade de exercer o seu múnus de maneira efetivamente independente. Nesse ponto específico, é de se destacar que o Supremo Tribunal Federal encontrou espaço propício para poder atuar como um relevante ator político,uma vez que mais do quemero órgão de cúpula do Poder Judiciário,também assumiu a posição de Guardião da Constituição.

Bem diverso era o cenário em que o Poder Judiciário e, sobretudo, o Supremo Tribunal Federal se encontravam antes daConstituição de 1988. Por mais que no passado este tenha tido em seus quadros juristas notáveis, sua atuação, sob o ponto de vista político institucional ${ }^{1}$, era bastante tímida. E razões não faltaram para isso. As principais delas estão relacionadasaos longos períodos de instabilidade institucional e de experiências autoritárias. De fato, em contextos como estes o Poder Judiciário, por uma questão de autopreservação, tende a ser mais deferentes às decisões políticas dos demais Poderes, haja vista os riscos de sofrer ataques institucionais. Ao revés, é durante períodos de democracia e estabilidade política e institucional que se encontra o terreno fértil para o florescimentoda atuação livre e independente da jurisdição constitucional.

Ainda nesse tema, a história é repleta de exemplos de ataques institucionais sofridos pelo Poder Judiciário e,notadamente, pelas Cortes Supremas. Na história brasileira podem ser citados: as aposentadorias compulsórias de ministros ${ }^{2}$, as declarações de estados de sítio $^{3}$, o manejo no número de cadeiras da Corte ${ }^{4}$ e a indicação de quadros ou que não atendiam as qualificações necessárias para o cargo ou que eram alinhados ideologicamente aos regimes de exceção ${ }^{5}$.Além

\footnotetext{
${ }^{1}$ Como exemplodessa atuação até então tímida ou autocontida podem ser citados o Mandado de Segurança e o Habeas Corpus (HC 33.908 Rel. Min. Ary Franco, e MS 3.557 Rel. Min. Hahnemann Guimarães) julgados em conjunto pelo STF, por ocasião da tentativa do Vice Presidente Café Filho em tentar reassumir a Presidência da República, após o suicídio de Getúlio Vargas. O célebre voto do Ministro Nélson Hungria fala em "impossibilidade material" de Café Filho reassumir a Presidência da República "em face da imposição dos tanke e baionetas do Exército", que estariam acima das leis, da Constituição e do Supremo Tribunal Federal. Esclarece ainda que contra uma insurreição vitoriosa pelas armas somente seria viável uma contrainsurreição de maior força.

${ }^{2}$ A Carta de 1937 reduziu a idade para aposentadoria compulsória dos juízes de 75 para 68 anos, o que de imediato provocou a saída de 5 ministros da Corte. Nesse sentido, v. RODRIGUES, Leda Boechat. História do Supremo Tribunal. Apud: SOUZA NETO, Cláudio Pereira de.; SARMENTO, Daniel. Direito Constitucional: teoria, história e métodos de trabalho. - 2. ed., 3. reimpr. Belo Horizonte: Fórum, 2017, p. 126.

3 Embora a declaração de estado de sítio não possa ser considerada per se um ataque institucional ao Poder Judiciário, resta claro que, durante a sua vigência, a independência e protagonismo judicial tendem a estar ameaçadas. E isso porque este se caracteriza como um período de anormalidade (excepcionalidade) institucional em que ocorre a centralização de Poderes na figura do Chefe do Poder Executivo. Ao longo da República a declaração de Estado de sítio foi, por vezes, manejada de forma arbitrária. Cite-se, como exemplo, o Governo de Artur Bernades (1922-1926) que foi exercido integralmente sob estado de sítio.

${ }^{4} \mathrm{O}$ AI-2, por exemplo, ampliou o número de cadeiras no STF para 16, o que permitiu a indicação Ministros alinhados ideologicamente ao regime autoritário e, consequentemente, permitiu a formação de uma maioria ampla na Corte. SOUZA NETO, Cláudio Pereira de.; SARMENTO, Daniel. Direito Constitucional: teoria, história e métodos de trabalho. Op., cit., p. 141.

5 A Constituição de 1891 não previa o notável saber jurídico, mas tão somente "notável saber" como uma das condições para a investidura no cargo de Ministro do Supremo Tribunal Federal. Nesse aspecto, Floriano Peixoto nomeou algumas pessoas sem formação jurídica, como o médico Barata Ribeiro, com o intuito de desprestigiar a
}

Revista de Direito Brasileira | Florianópolis, SC | v. 23 | n. 9 | p. 147-171 |Mai./Ago. 2019 
da experiência brasileira, as de outros países democráticos ${ }^{6}$ provam ser verdadeira a assertiva de que o Judiciário seria o "Poder menos perigoso", uma vez que não possui nem a espada e nem a chave do cofre ${ }^{7}$.

Sendo assim, é forçoso se realçar uma relação direta entre o estabelecimento de uma ordem política institucionalmente estável e democrática - a partir de 1988 - com a progressiva expansão, ascensão e protagonismo do Poder Judiciário. E, de fato, pordiversasvezes, ao longo desses trinta anos, a agenda do Supremo Tribunal Federal esteve repleta de casos de elevada envergadura política, social e econômica, alguns do quais assumiram posição de centralidade nos debates e discussões da sociedade e da opinião pública. Deste modo, é inegável a afirmação de que, hoje, o Judiciário brasileiro se constitui efetivamente como um importante ator político no cenário nacional.

Todavia, deveser resguardadacerta cautela com a utilização da expressão "supremacia judicial", mesmo sob a égide da Carta de 1988. Apesar de o Poder Judiciário ser atualmente institucionalmente mais forte e mais independente, isso não significa que é um Poder onipotente. Na verdade, a melhor posição a serabraçada seria a que aduz que no ordenamento jurídico pátrio não existe adita supremacia de quaisquer dos Poderes. A hipótese aventada é de que a Separação de Poderes propicia verdadeiro equilíbrio entre eles, no qual, diante de temas complexos ou salientes, cadaum pode contribuir para a construção de soluções a partir de diálogos, tendo-se como referência as suas respectivas capacidades institucionais. Nesse sentido, alguns trabalhos já tiveram a oportunidade de demonstrar empiricamentea ilusão de uma concepção de Supremacia Judicial no contexto pós 1988 , em que pese a inegável ascensão do Judiciário no período ${ }^{8}$.

Ademais, na práxis da jurisdição constitucional, a partir da Constituição de 1988, outro fator deve ser considerado: a atribuição ao Supremo Tribunal Federal de competências superlativas. Concretamente o próprio funcionamento da Corte como órgão colegiado fica prejudicado, uma vez que para julgar um excessivo número de processos, inevitavelmente, os Ministros devem se utilizar de forma acentuada de competências monocráticas ou individuais. Diante disso, o presente artigo analisará o fenômeno e buscará demonstrar que uma concepção de supremacia ou de "supremocracia" aliada à expansão excessiva de competências monocráticas do Supremo Tribunal Federal,além de negativa do ponto de vista democrático, representativo e deliberativo pode suscitar refluxos deletérios sob a perspectiva institucional. A partir daí será construída uma análise crítica, que caminhará na tentativa de propor soluções e alternativas.

Corte. Tais nomeações, no entanto, não foram aprovadas pelo Senado Federal. SOUZA NETO, Cláudio Pereira de.; SARMENTO, Daniel. Direito Constitucional: teoria, história e métodos de trabalho. Op., cit., p. 111-112.

6 Talvez um dos exemplos mais emblemáticos tenha sido a ameaça de court packing plan de FranklinRoosevelt contra a Suprema Corte Americana. O pano de fundo eram as reformas do New Deal, no qual o presidente norte americano lançou mão de várias medidas de intervenção estatal na Economia. Algumas dessas medidas foram questionadas e invalidadas por uma Suprema Corte Americana bastante conservadora e ativista, no que ficou conhecida como Era Lochner. Basicamente, o court packing plan consistia em alterações legislativas propostas pelo Presidente norte americano no sentido de aumentar o número de cadeiras na Suprema Corte, de modo que pudesse contar com uma maioria e, consequentemente, não ter as suas reformas invalidadas. Nesse caso, não houve propriamente a alteração legislativa, mas a ameaça de ataque institucional foi capaz de fazer com que alguns justices passassem a se portar de forma mais deferente às escolhas políticas do Poder Executivo. Nesse sentido v. ACKERMAN, Bruce A.. The Failure of the founding fathers - Jefferson, Marshall and the rise of the presidential democracy. Cambridge, Massachusetts: Harvard University Press, 2005, p. 245-266.

${ }^{7}$ A clássica obra "The federalist papers" em seu $n^{0} .78$ já enunciava essa assertiva. Veja a seguinte passage: "(...) the judiciary, on the contrary, has no influence over either the sword or the purse; no direction either of the strength or of the wealth of the society, and can take no active resolution whatever. It may truly be said to have neither FORCE nor WILL but merely judgment; and must ultimately depend upon the aid of the executive arm even for the efficacy of its judgments". HAMILTON, Alexander; MADISON, James; JAY, John. The Federalist papers. Mineola, Nova Iorque; Dover thrift editions, 2014, p. 379.

${ }^{8}$ BRANDÃO, Rodrigo. Supremacia judicial versus diálogos constitucionais: a quem cabe a última palavra sobre o sentido da Constituição?. - Rio de Janeiro: Lumen Juris, 2017.

${ }^{9}$ VIEIRA, Oscar Vilhena. Supremocracia. In: Revista direito GV, São Paulo 4(2) | p. 441-464|jul-dez 2008.

Revista de Direito Brasileira | Florianópolis, SC | v. 23 | n. 9 | p.147-171 |Mai./Ago. 2019 


\section{DA SUPREMACIA JUDICIAL À DOUTRINA DOS DIÁLOGOS CONSTITUCIONAIS}

\subsection{Condições para a ascensão e expansão do Supremo Tribunal Federal}

Conforme introduzido no tópico anterior, a Constituição Federal de 1988 propiciou a assunção de um papel de maior destaque por parte do Poder Judiciário - e por consequência do Supremo Tribunal Federal - na vida econômica, social, política e institucional do país. De um lado, esse fenômeno pode ser atribuído a algumas previsões de caráter institucional da Constituição. De fato, foram positivadas garantias substantivas e robustas à magistratura, consubstanciadas na inamovibilidade, na vitaliciedade e na irredutibilidade de vencimentos. Tais previsões normativas, expressas no art. 95 da $\mathrm{CF}$, possuem o escopo notório e já sabido de conferir uma atuação mais independente ao exercício da função típica do Poder Judiciário.

Por outro lado, especificamente em se tratando do Supremo Tribunal Federal, foi atribuída à Corte aposição de Guardião da Constituição. Mais do que isso, a Constituição também lhe conferiu competências superlativas. Não apenas a partirda simples leitura doartigo 102 da Carta Magna, mas também através da observância da experiência prática percebe-se que um sem número de demandas,sem objetos tipicamente atinentes ao exercício dajurisdição de uma Corte Suprema, acaba ingressando em sua agenda. Apesar de algumas reformas pontuais terem lançado mão de alternativas a essa problemática, fato é que ainda hoje há a possibilidadede o Supremo ou os seus ministros monocraticamente - julgarou apreciardemandas de poucarelevância político institucional ou de baixa repercussão geral.

O problema das competências superlativas combinado com a uma cultura de litigância exacerbadaé um ponto que será retomado mais a frente. É importante realçar neste momento apenas as previsões constitucionais das competências do Supremo Tribunal Federal em sede de controle de constitucionalidade. A ampliação do controle de constitucionalidade abstrato através dacriaçãoda ação direta de constitucionalidade (ADIn), da ação declaratória de constitucionalidade (ADC), da ação direta de inconstitucionalidade por omissão (ADIn-O), da arguição de descumprimento de preceito fundamental (ADPF) e, obviamente, a possibilidade de se conferir efeitos erga omnes e vinculantes em ações concretas, seja por meio de repercussão geral ou da aprovação de súmulas vinculantes, por evidente, são fatores que contribuíram para um rearranjo institucional no Brasil.

É preciso destacar que antes de 1988 havia apenas uma ação de controle abstrato no ordenamento jurídico pátrio: a Representação Interventiva ${ }^{10}$. Esta ação pode ser considerada como um embrião da atual ADIn. No entanto, o seu uso, concretamente, era bastante ineficaz. Isso porque o único legitimado ativo para propô-la era o Procurador Geral da República, que, por sua vez, era um cargo de livre nomeação e exoneração pelo Chefe do Executivo. Logo, é sintomático que não tenha sido amplamente manejada na prática, exceto quando era do interesse do Governo Militar.

Pós 1988 esse cenário muda radicalmente. Há uma notável ampliação do rol dos legitimados ativos para a propositura de ações abstratas, além do fato já referido de que algumas ações concretas a passaram a poder ser decididas pelo Supremo com efeitos erga omnes e vinculantes. Uma vez que o controle abstrato começa a se espraiar pela práxis, a importância do Supremo Tribunal Federal em termos políticos começa a se revelar de uma maneira nunca antes vista na história nacional.

\footnotetext{
${ }^{10}$ A representação interventiva inaugurou o controle abstrato no direito brasileiro, tornando o sistema de controle de constitucionalidade misto. Tal ação foi introduzida pela EC 16/65 à Constituição de 1946. Nesse ponto, v. SOUZA NETO, Cláudio Pereira de.; SARMENTO, Daniel. Direito Constitucional: teoria, história e métodos de trabalho. - 2. ed., 3. reimpr. Belo Horizonte: Fórum, 2017, p. 141.
}

Revista de Direito Brasileira | Florianópolis, SC | v. 23 | n. 9 | p. 147-171 |Mai./Ago. 2019 
Desde a promulgação da Constituição até a presente data dois fenômenos merecem destaque especial na atuação do Supremo Tribunal Federal. O primeiro é o da judicialização da política $^{11}$. Em razão do crescimento da complexidade e polarização que o Estado brasileiro vivenciou nos últimos 30 anos além, é claro, da existência de uma Constituição demasiadamente analítica, as deliberações de cunho político não costumam se encerrar nas Casas Legislativas. Projetos de Governo ou mesmo de reforma do Estado Brasileiro, por meio de leis ou Emendas Constitucionais, são atacados judicialmente pelos vencidos na Arena Política ${ }^{12}$. E de fato, por vezes a nossa Suprema Corte talvez tenha assumido uma postura ativista ${ }^{13}$ nesse sentido. Evidentemente, uma tal atuação da Cortepode propiciar discussões já seculares, em outros ordenamentos jurídicos, por uma suposta ausência de legitimidade democrática, o que, destaquese, não é objeto deste estudo.

Em segundo lugar, o Supremo Tribunal Federal foi diversas vezes chamado a decidir os chamados casos difíceis ${ }^{14}$. Como exemplos podem ser citados os casos da interrupção de gestação de fetos anencefálicos(ADPF 54, Rel. Min. Marco Aurélio, j. 10/05/2013), das uniões homoafetivas (ADPF 132, Rel. Min. Luiz Fux, j. 03/11/2014), das biografias não autorizadas (ADIn 4.815, Rel. Min. Cármen Lúcia, j. 16/02/2016), das pesquisas com células tronco embrionárias (ADIn 3.510, Rel. Min. Ayres Britto, j. 28/05/2010) e do financiamento de campanhas eleitorais (ADIn 4.650, Rel. Min. Luiz Fux, j. 08/03/2016). A atuação do Supremo em casos difíceis - muitas vezes decidindo com base em princípios muito abstratos, como o da dignidade da pessoa humana - revelauma dimensão decisória em muitos aspectos de cunhomoral e/ou político. Sem dúvidas, esse fenômeno pode vir a ser inescapável, uma vez que os próprios quadros políticos não regulamentam de forma satisfatória muitas das questões discutidas em tais casos, deixando-as entãopara serem definidas pelo Supremo, seja por inércia ou falta de interesse, seja por questão de autopreservação político-eleitoral.Pode-se também afirmar que o "boom" de casos difíceis, ocorrido a partir da Constituição de 1988, se justificaria em certa medidaem razão de uma cultura pós positivista ${ }^{15}$ na forma de interpretar o direito, do aumento da complexidade da vida pós moderna e da normatividade dos princípios jurídicos e suas recorrentes colisões concretas.

É preciso dizer, no entanto, que essa expansão judicial não seria nem um pouco viável apenas pela previsão formal de competências constitucionais amplas e de garantias institucionais. De fato, a experiência constitucional brasileira ao longo de quase dois séculos demonstra certo desapego pelo cumprimento de regras e princípios expressamente previstos na Constituição e na legislação, de modo geral. Um ponto decisivo para a ascensão do Supremo Tribunal Federal foi,

\footnotetext{
${ }^{11}$ Sobre o fenômeno da judicialização da política v. GRIMM, Dieter. Constituição e Política. - Tradutor: Geraldo de Carvalho. Belo Horizonte: Del Rey, 2006; BRANDÃO, Rodrigo. A judicialização da política: teorias, condições e o caso brasileiro. In: RDA - revista de Direito Administrativo, Rio de Janeiro, v. 263, p. 175-220, maio/ago. 2013.

${ }^{12}$ Esclareça-se que não somente por demandas dos ditos vencidos ocorre a judicilização da política. Em outras ocasiões os atores políticos podem propositalmente se abster de deliberar matérias tipicamente de suas competências, em razão do elevado ônus político em decidir. Destarte, permitem a atuação da Suprema Corte, sobretudo em face de seu insulamento político.

13 Ao contrário da judicialização, que é um fato, o ativismo é uma atitude de deliberada expansão do Poder Judiciário, mediante a utilização de interpretação judicial. Nesse aspecto, por vezes a postura ativista acaba fazendo com que o Judiciário se sobreponha aos demais Poderes em suas funções típicas, como por exemplo, no campo das políticas públicas. Nesse sentido, v. BARROSO, Luís Roberto. O novo direito constitucional brasileiro: contribuições para a construção teórica e prática da jurisdição constitucional no Brasil. - 3. Reimpressão. - Belo Horizonte: Fórum, 2014, p. 39-40.

${ }^{14}$ Os casos difíceis seriam aqueles em que não há uma solução pré-pronta no ordenamento jurídico, hipótese na qual ela deverá ser construída argumentativamente pelo intérprete, a partir de parâmetros normativos e de parâmetros externos às normas. Sobre os casos difíceis v. BARROSO, Luís Roberto. O novo direito constitucional brasileiro: contribuições para a construção teórica e prática da jurisdição constitucional no Brasil. Op., cit., p. 37.

15 Para uma visão ampla sobre as circunstâncias que propiciaram o surgimento do pós positivismo v. BARROSO. Luís Roberto. Curso de Direito Constitucional Contemporâneo: Os conceitos fundamentais e a construção de um novo modelo. - 6a ed. - São Paulo: Saraiva, 2017, p. 261-284.
}

Revista de Direito Brasileira | Florianópolis, SC | v. 23 | n. 9 | p.147-171 |Mai./Ago. 2019 
sem dúvidas, a doutrina brasileira da efetividade ${ }^{16}$. Em síntese, trata-seda doutrina capitaneada na década de 1980 por Luís Roberto Barroso, que tinha como escopo a valorização do direito constitucional, de forma que a Constituição passasse a valer efetivamente como norma e não apenas como uma mera emanação política. Nessa situação, o Poder Judiciário teria uma atuação decisiva na concretização das normas constitucionais.

A partir da concepção de que a Constituição é norma jurídica e que seus preceitos podem (e devem) ser efetivados na prática, ao Supremo Tribunal Federal, no exercício da função de intérprete e Guardião da Constituição, foi atribuída a posição de "supremacia", que, em síntese, implicaria na prerrogativa de dar a última palavra sobre as demandas que lhes são submetidas. No entanto, apesar da inegável expansão da jurisdição constitucional, pode-se questionar se essa prerrogativa de proferir a última palavra é realmente verídica, o que será feito nos tópicos seguintes.

\subsection{Que Supremacia? Breves notas sobre as experiências norte americana e brasileira}

Talvez a maior parte das aulas, trabalhos e artigos acadêmicos que tratam do controle de constitucionalidade como objeto principal se debrucem em algum momento sobre a paradigmática decisão da Suprema Corte Americana no caso Marbury vs. Madison, de 1803. A história contada normalmente se orienta no sentido de que o Chief Justice, John Marshall, de forma perspicaz, interpretou a Constituição Norte-Americana no sentido de criar o controle de constitucionalidade - visto que tal competência não era prevista expressamente - e conferir ao Judiciário o status de supremacia, uma vez que este teria a prerrogativa de "proferir a última palavra".

Todavia, é certo que alguns trabalhos analisaram mais profundamente essa história para desmitificar tal visão ${ }^{17}$. Embora, não seja este o espaço para esmiuçar toda a riqueza de detalhes da história de Marbury vs. Madison, que se referem tanto a fatos anteriores quanto posteriores à decisão propriamente dita,será trazido um breve resumo do caso, de cunho meramente ilustrativo.

Na passagem do século XVIII para o século XIX, os EUA viviam um clima político assaz conturbado, visto que os Federalistas e os Republicanos disputavam não somente os lugares no Governo, mas também, ideologicamente, o próprio sentido das instituições, até então bastante recentes. Nesse contexto, o governo Federalista sofre uma derrota nas urnas com a eleição do Republicano Thomas Jefferson, em 1801. No meio termo entre o resultado das eleições e a posse efetiva do novo presidente, o Presidente Federalista John Adams realiza uma série de nomeações - muitas das quais tidas como desnecessárias, através do Judiciary Act-de correligionários do partido Federalista para cargos judiciários, que passam a ser conhecidos como os midnight judges $^{18}$. Uma dessas nomeações foi a de seu Chefe de Gabinete, John Marshall, para a presidência da Suprema Corte, que foi aquele que, até aquele momento, coordenara as demais nomeações. Ocorre que, em face do prazo exíguo e do elevado número de nomeações, Marbury, que havia sido nomeado para o cargo de juiz de paz no distrito de Columbia, não consegue efetivamente tomar posse. E o Chefe de Gabinete do novo governo, Madison, se recusa a lhe dar posse, mesmo aquele estando com o termo de nomeação em mãos.

O caso acaba sendo judicializado e chega à Suprema Corte. Quem fica responsável por proferir a decisão é justamente o Chief Justice, John Marshall, que estaria claramente diante de uma hipótese de impedimento judicial. Nada obstante, profere mesmo assim a decisão- que ao

\footnotetext{
${ }^{16}$ BARROSO, Luís Roberto. O novo direito constitucional brasileiro: contribuições para a construção teórica e prática da jurisdição constitucional no Brasil. Op., cit., p. 26-28.

${ }^{17}$ ACKERMAN, Bruce A.. The Failure of the founding fathers - Jefferson, Marshall and the rise of the presidential democracy. Op., cit..

${ }^{18}$ SOUTO, João Carlos. Suprema Corte dos Estados Unidos - principais decisões. - 2. ed. - São Paulo: Atlas, 2015, p. 13-19.
}

Revista de Direito Brasileira | Florianópolis, SC | v. 23 | n. 9 | p. 147-171 |Mai./Ago. 2019 
menos deve ser elogiada por sua perspicácia. Em primeiro lugar, inverte a ordem do julgamento, analisando o mérito antes das questões preliminares. Nesse sentido, afirma que, a princípio,William Marbury possuiriarealmente direito subjetivo à nomeação. No entanto, ao analisar em um segundo momento as questões preliminares, afirma que a Suprema Corte não poderia julgar a questão por falta de competência, uma vez que a lei que lhe atribuíra essa competência seria inconstitucional. E isso porque somente a Constituição poderia atribuir competências à Suprema Corte. Desse modo, Marshall profere uma decisão capaz de agradar ao mesmo tempo Republicanos e Federalistas, abrindo terreno para o exercício do controle de constitucionalidade das leis, que já havia sido enunciado no Federalista n. 78, de Alexander Hamilton, James Madison e John Jay ${ }^{19}$.

O grande equívoco das análises tradicionais desse caso emblemático talvez seja o de apenas destacar o protagonismo do Poder Judiciário em se auto atribuir uma competência de controle de constitucionalidade sobre os atos normativos dos Poderes Majoritários. Isso, em última análise, seria a fonte da supremacia judicial. Ocorre que essa é uma visão insuficiente. $\mathrm{O}$ estudo das conjunturas pré e pós decisão de Marbury vs. Madison denotam a existência de uma intensa interação entre o Poder Judiciário e os Poderes políticos ${ }^{20}$.

É preciso, por exemplo, se entender que os Republicanos naturalmente não ficaram satisfeitos com a aprovação de umJudiciary Act pelos Federalistas e com a nomeação dos midnight judges, haja vista que estas foram compreendidas como subterfúgio de infiltração Federalista no Governo Republicano ${ }^{21}$. Diante disso, o Judiciary ActFederalista foi revogado através da aprovação de um novo estatuto pelos Republicanos, no qual alguns, juízes, denominados decircuit judges, já nomeados foram afastados. Além disso, a sessão da Suprema Corte Americana de junho de 1801 foi cancelada, a qualseria um momento propício para análise da constitucionalidade darevogação do Judiciary Act Federalista.

Deve-se também interpretar Marbury vs. Madison em conjunto com o caso Stuart vs. Laird, de 1803, decidido uma semana depois daquele. O caso ${ }^{22}$ foi incialmente decidido por um juiz de primeira instância, durante a vigência o Judiciary Act, de 1801, mas, durante o processo de execução, o magistrado que havia proferido a decisão não mais existia em razão doRepublican Judiciary Act Repeal, de 1802 e, por isso,acabou sendo ajuizada em uma circuit court que existia antes da reforma de 1801 . Nessa circuit court, pleiteou-se que a execução não poderia prosseguir perante outro juízo que não havia proferido a decisão, além de pleitear a inconstitucionalidade da lei republicana de 1802, que reestabelecia uma competência da Suprema Corte que não tinha previsão na Constituição - isto é, a atuação dos justices da Suprema Corte nas circuit courts.

Em apelação dirigida à Suprema Corte, Marshall se declara impedido e a decisão é redigida pelo justice Paterson. O justice Paterson se orienta no sentido de reconhecer a autoridade do Congresso dos EUA em estabelecer tribunais inferiores e transferir uma causa de um tribunal para o outro sempre que necessário, além de entender pela possibilidade de os membros da Suprema Corte atuarem comocircuit courts, pois esta seria uma prática longeva, que remontaria ao começo da organização do sistema judicial, fixado por uma construção constitucional demasiadamente sólida para ser alterada ou controlada ${ }^{23}$. Em síntese, com esse julgado a

\footnotetext{
${ }^{19}$ HAMILTON, Alexander; MADISON, James; JAY, John. The Federalist papers. Op. cit., p. 380-384.

${ }^{20}$ ACKERMAN, Bruce A.. The Failure of the founding fathers - Jefferson, Marshall and the rise of the presidential democracy. Op. cit. p. 224-244.

21 BRANDÃO, Rodrigo. O outro lado de Marbury V. Madison. Artigo publicado em 11.04.2015 no site <http://www.osconstitucionalistas.com.br/o-outro-lado-de-marbury-v-madison>. Acesso em 10.10.2017..

${ }^{22} \mathrm{O}$ pano de fundo do caso foi o afastamento de Stuart, através do Judiciary Act. Ao contrário do caso Marbury vs. Madison não se tratava de juiz de paz,, mas de um circuit judge, que ao contrário daquele possuía a garantia da vitaliciedade. A discussão, em suma, envolvia a possibilidade de extinção de cargos vitalícios em razão do argumento de ilegitimidade de seu provimento, tendo em vista a tentativa de infiltração política dos Federalistas no governo Republicano.

${ }^{23}$ SOUTO, João Carlos. Suprema Corte dos Estados Unidos - principais decisões. Op., cit., p. 36.
}

Revista de Direito Brasileira | Florianópolis, SC | v. 23 | n. 9 | p.147-171 |Mai./Ago. 2019 
Suprema Corte Americana se posicionou pela validade das alterações realizadas pelo Judiciary ActRepublicano, de 1802, evitando o confronto direto com o Governo de Thomas Jefferson ${ }^{24}$.

O destaque é que em ambos os casos o advogado atuante perante a Suprema Corte foi Charles Lee. A tese deste foi de que os fundamentos utilizados em Marbury vs. Madison se encaixariam perfeitamente em Stuart vs. Laird,isto é, tanto a questão do direito subjetivo à nomeação, quanto a impossibilidade de alteração das competências da Suprema Corte por meio de lei.Com efeito, caso fossem adotados os fundamentos do primeiro julgamento, o resultado lógico seria a procedência do segundo. No entanto, como dito acima, a Suprema Corte, em uma atitude de auto preservação institucional, denegou o pedido formulado em Stuart vs. Laird, demonstrando deferência às decisões políticas do Governo Republicano.

Também deve ser realçado o processo de impeachment que o justiceSamuel Chase, da Suprema Corte, sofreu em 1805, sobretudo em razão de seu posicionamento público, claramente alinhado aos Federalistas. Na Câmara dos Deputados o processo de impeachment foi aberto, tendo assumido um caráter mais político do que técnico. Já no Senado o impeachment foi julgado tal qual um processo judicial ${ }^{25}$, mas não foi adiante em razão de não ter sido alcançado o quórum necessário de dois terços dos Senadores para a aprovação das várias acusações sofridas ${ }^{26}$.

Portanto, a leitura conjunta entre Marbury vs. Madison, Stuart vs. Laird e o impeachment de Samuel Chase denotam a existência de um verdadeiro jogo institucional entre os poderes constituídos, na tentativa de implementação e consolidação de visões constitucionais e políticas particulares. Mais do que isso, foi uma "campanha" repleta de avanços e retiradas, especialmente por parte do Judiciário, que atuou igualmente com oescopo de autopreservação, longe, portanto, de uma pretensa supremacia judicial.Assim, parece correta a visão de que tal período denota um "sofisticado diálogo em que cada instituição contribuiu com a lógica que lhe é própria para a construção de entendimentos constitucionais".Além do mais, esse processo dialógico nos primórdios do constitucionalismo norte americano permitiu uma "síntese ${ }^{27}$ " entre as diversas visões sobre as instituições, o que impediu qualquer pretensão de ruptura constitucional $^{28}$.

A experiência brasileira, por sua vez, certamente não possui um evento tão paradigmático quanto Marbury v. Madison. Todavia, é evidente que alguns casos concretos que chegaram ao crivo do Supremo Tribunal, pós 1988, demonstram que a Corte nem sempre terá a última palavra - ou, ao menos, como efetivar determinada decisão, em que pese a evidência do direito. E mais, em tempos de elevada polarização e exposição da classe política, o próprio

\footnotetext{
${ }^{24}$ BRANDÃO, Rodrigo. O outro lado de Marbury V. Madison. Op. cit.

${ }^{25}$ BRANDÃO, Rodrigo. O outro lado de Marbury V. Madison. Op. cit.

${ }^{26}$ Foram oito as acusações - a maior parte sem fundamentos consistentes - sofridas pelo justice Samuel Chase em seu processo de impeachment, o único da história dos EUA contra um juiz da Suprema Corte. Para uma breve explicação sobre o processo v.<https://www.conjur.com.br/2014-jan-05/embargos-culturais-tentativa-impeachmentsamuel-chase-estados-unidos $\geq$, Acesso em 30.10.2017. O resultado e o modo de julgamento realizado pelo Senado foram essenciais para a afirmação da independência judicial.Ao revés, aduz-se que o desfecho possivelmente teria sido outro caso a Suprema Corte houvesse desafiado os republicanos em Stuart vs. Laird.

${ }^{27}$ ACKERMAN, Bruce A.. The Failure of the founding fathers - Jefferson, Marshall and the rise of the presidential democracy. Op. cit. 224-244.

${ }^{28}$ É interessante notar que o presidente republicano Thomas Jefferson, uma das figuras centrais desses casos paradigmáticos possuía a visão de que as diferentes mentes de cada geração deveriam estampar suas visões de mundo na Constituição, ainda que isso significasse a promulgação de uma nova Constituição. Ou seja, era a visão que buscava evitar conflitos intergeracionais na medida em que não se formasse"um governo dos mortos sobre os vivos". Em que pese seu posicionamento nesse sentido, o resultado dos acontecimentos políticos do início do século XIX conferiram nas décadas seguintes certa primazia política aos republicanos, o que de alguma forma contribui para a consolidação e estabilização não apenas da Constituição dos EUA - sem dúvidas uma das mais longevas -, mas também das próprias instituições. Nesse sentido, v. SUNSTEIN, Cass R.. A constitution of many minds. Nova Jersey: Princeton University, 2009.
} 
Tribunal acaba por adotar posturas autocontidas e deferentes aos demais poderes, em certas ocasiões.

Nesse ponto, podemos falar inicialmente das ações que visam à supressão de alguma espécie de omissão no ordenamento jurídico - isto é, ação direta de inconstitucionalidade por omissão e o mandado de injunção. É intuitivo que em muitas hipóteses o Judiciário não pode ir muito longe. No máximo cientificará a mora legislativa ou então tentará, de alguma forma, integrar o vácuo legislativo. Mas o fato é: na primeira hipótese nada de muito relevante acontecerá caso os poderes majoritários não demonstrem disposição em realizar seu dever de legislar. Já a segunda hipótese pode resultar em decisões potencialmente desastrosas, seja pela falta de capacidade institucional para legislar sobre determinada matéria, seja pela possibilidade de atrito com os poderes políticos, o que exige uma natural autocontenção e cautela por parte dos juízes.

Entretanto, não apenas no contexto das omissões constitucionais a pretensa supremacia judicial é equivocada ${ }^{29}$. Três casos concretos brasileiros bem distintos em seus contextos e fundamentos podem servir para demonstrar a incapacidade de o Judiciário ser tomado como um poder supremo, isolado e soberano. Ao revés, demonstram a imperiosa necessidade de uma interação equilibrada entre os demais poderes, caso de fato pretenda proferir decisões em searas de elevada relevância econômica, social ou político-institucional.

O primeiro caso trata-se da Inconstitucionalidade do salário mínimo (ADIn 1458-7, Rel. Min. Sepúlveda Pertence, j. 31/10/2001).Em um primeiro momento foi analisada a medida cautelar na referida ADIn. Apesar de o pedido ter sido formulado através de ação direta de inconstitucionalidade, o relator reconheceu que se tratava de questão atinente à omissão do poder público em fixar o valor do salário mínimo, nos termos do que impõe art. $7^{\circ}$, IV CF. No caso,o relator até chegou a reconhecer a inconstitucionalidade parcial do valor nominal do salário mínimo $^{30}$, mas houve a impossibilidade de concessão da medida liminar, uma vez queo julgamento ocorreu em uma época em que as omissões constitucionais eram apenas cientificadas ao Poder omisso. Posteriormente, o relator, ao acolher parecer do PGR, julgou a ação prejudicada, em razão de a ADIn não ter sido aditada, tendo em vista as alterações legislativas na matéria. Em que pesem as contingências do caso concreto, pode-se afirmar que, ainda hoje, o valor do salário mínimo não atende às especificações do art. $7^{\circ}$, IV CF de forma satisfatória. Ou

\footnotetext{
${ }^{29}$ Conforme será demonstrado ao longo do trabalho, outra hipótese que põe em xeque a noção de supremacia judicial é a possibilidade de superação normativa de decisões da Suprema Corte. No Brasil, essa superação normativa ocorreu algumas vezes através da aprovação de Emendas Constitucionais. Citem-se como exemplo a EC 29/2000, que permitiu a progressividade do IPTU em razão do valor venal do imóvel, em oposição à decisão no RE 153.771, ou ainda a EC 19/1988, que inseriu vantagens de caráter pessoal para fins de cálculo do teto remuneratório, em oposição à decisão na ADIn 14. Para um estudo mais detalhado dos casos de Emendas Constitucionais tendentes a superar jurisprudência do STF v.BRANDÃO, Rodrigo. Supremacia judicial versus diálogos constitucionais: a quem cabe a última palavra sobre o sentido da Constituição?. Op., cit., p. 357-370.

${ }^{30}$ Veja o seguinte trecho da ementa da medida cautelar: “(...)A insuficiência do valor correspondente ao salário mínimo, definido em importância que se revele incapaz de atender as necessidades vitais básicas do trabalhador e dos membros de sua família, configura um claro descumprimento, ainda que parcial, da Constituição da República, pois o legislador, em tal hipótese, longe de atuar como o sujeito concretizante do postulado constitucional que garante à classe trabalhadora um piso geral de remuneração (CF, art. $7^{\circ}$, IV), estará realizando, de modo imperfeito, o programa social assumido pelo Estado na ordem jurídica. - A omissão do Estado - que deixa de cumprir, em maior ou em menor extensão, a imposição ditada pelo texto constitucional - qualifica-se como comportamento revestido da maior gravidade político-jurídica, eis que, mediante inércia, o Poder Público também desrespeita a Constituição, também ofende direitos que nela se fundam e também impede, por ausência de medidas concretizadoras, a própria aplicabilidade dos postulados e princípios da Lei Fundamental. - As situações configuradoras de omissão inconstitucional - ainda que se cuide de omissão parcial, derivada da insuficiente concretização, pelo Poder Público, do conteúdo material da norma impositiva fundada na Carta Política, de que é destinatário - refletem comportamento estatal que deve ser repelido, pois a inércia do Estado qualifica-se, perigosamente, como um dos processos informais de mudança da Constituição, expondo-se, por isso mesmo, à censura do Poder Judiciário (...)”. Grifos nosso.
}

Revista de Direito Brasileira | Florianópolis, SC | v. 23 | n. 9 | p.147-171 |Mai./Ago. 2019 
seja, é ilusório pensar que o valor atual do salário mínimo ${ }^{31}$ seja capaz de atender as necessidades básicas dos trabalhadores - com moradia, saúde, educação, alimentação, vestuário, transporte, higiene, lazer e previdência social - e de sua família. Ocorre que qualquer ingerência do Poder Judiciário nessa matéria, fixando um valor nominal que considere constitucionalmente adequado, teria efeitos sistêmicos desastrosos sobre toda economia do país. Daí a necessidade que a Corte assuma uma postura pragmática e relegue o tema ao Executivo e ao Legislativo.

O segundo caso trata-se do pedido de declaração de um estado de coisas inconstitucional em todo o sistema penitenciário brasileiro (ADPF 347 MC, Rel. Min. Marco Aurélio, j. 19/02/2016). A ação foi ajuizada pelo PSOL em 2015, ante a existência de violações gravíssimas e estruturais em todo o sistema prisional brasileiro, no que tange aos direitos fundamentais dos detentos. Em uma decisão até então inédita, a Corte em sede liminar reconheceu a ocorrência do dito estado de coisas inconstitucional ${ }^{32}$. A expressão advém da jurisprudência colombiana, que possui uma notável prática em ações dessa espécie, conhecidas comodemandas estruturais ${ }^{33}$.

Em síntese as demandas estruturais são aquelas envoltas em uma elevada complexidade, tanto em termos de violações - podem estar ocorrendo sistemáticas ações ou omissões inconstitucionais - quanto de agentes violadores, de modo que, para se superar esse estado de coisas, é necessária uma efetiva ação sobre os próprios alicerces da conduta estatal. E de fato, os recorrentes abusos e violações de direitos humanos no sistema penitenciário brasileiro demandam não apenas a ação isolada do Poder Judiciário, mas uma efetiva ação concertada entre todos os Poderes da República. A situação se torna mais complexa em razão da organização federativa brasileira, em que cada Estado da Federação acaba gerindo suas penitenciárias. Além do mais, a complexidade das demandas estruturais exige um necessário processo de monitoramento, avaliação e reavaliação dos resultados de decisões e medidas implementadas ${ }^{34}$. Portanto, é de se reconhecer que a técnica mais adequada para se decidir demandas estruturais envolve as decisões dialógicas. É dizer: a simples declaração de inconstitucionalidade ou de violação a preceito

\footnotetext{
${ }^{31}$ O Decreto Federal 9.255/2017 fixou o piso nacional do salário mínimo em 954,00 reais.

${ }^{32}$ A ementa da medida cautelar possui a seguinte redação: "CUSTODIADO - INTEGRIDADE FÍSICA E MORAL - SISTEMA PENITENCIÁRIO - ARGUIÇÃO DE DESCUMPRIMENTO DE PRECEITO FUNDAMENTAL ADEQUAÇÃO. Cabível é a arguição de descumprimento de preceito fundamental considerada a situação degradante das penitenciárias no Brasil. SISTEMA PENITENCIÁRIO NACIONAL - SUPERLOTAÇÃO CARCERÁRIA CONDIÇÕES DESUMANAS DE CUSTÓDIA - VIOLAÇÃO MASSIVA DE DIREITOS FUNDAMENTAIS FALHAS ESTRUTURAIS - ESTADO DE COISAS INCONSTITUCIONAL - CONFIGURAÇÃO. Presente quadro de violação massiva e persistente de direitos fundamentais, decorrente de falhas estruturais e falência de políticas públicas e cuja modificação depende de medidas abrangentes de natureza normativa, administrativa e orçamentária, deve o sistema penitenciário nacional ser caraterizado como "estado de coisas inconstitucional". FUNDO PENITENCIÁRIO NACIONAL - VERBAS - CONTINGENCIAMENTO. Ante a situação precária das penitenciárias, o interesse público direciona à liberação das verbas do Fundo Penitenciário Nacional. AUDIÊNCIA DE CUSTÓDIA - OBSERVÂNCIA OBRIGATÓRIA. Estão obrigados juízes e tribunais, observados os artigos 9.3 do Pacto dos Direitos Civis e Políticos e 7.5 da Convenção Interamericana de Direitos Humanos, a realizarem, em até noventa dias, audiências de custódia, viabilizando o comparecimento do preso perante a autoridade judiciária no prazo máximo de 24 horas, contado do momento da prisão". O julgamento ainda não foi concluído.

${ }^{33}$ GLOPPEN, Siri et all. Courts and Power in Latin America and Africa. New York: Palgrave Macmillan, 2010, p. 42-43 e 52-55.

${ }^{34}$ No caso da ADPF 347 houve até a presente data o ingresso no processo de dez entidades na condição de amicus curiae, o que sem dúvida pode ser de inestimável valia para fins de monitoramento, em cada unidade da federação, das decisões tomadas. No entanto, mesmo assim é forçoso reconhecer que ainda há um longo caminho a se trilhar neste campo, especialmente em face de crises e rebeliões no sistema penitenciário ocorridas no início de 2017, amplamente divulgadas pela mídia. Como exemplo v.<http://g1.globo.com/bom-dia-brasil/noticia/2017/01/mortesem-presidios-do-pais-em-2017-ja-superam-o-massacre-do-carandiru.html $\geq e$

<http://www1.folha.uol.com.br/cotidiano/2017/08/1909315-seis-meses-apos-massacres-estados-ainda-tem-presidiossuperlotados.shtml $\geq$. Acesso em 30.10.2017.
}

Revista de Direito Brasileira | Florianópolis, SC | v. 23 | n. 9 | p. 147-171 |Mai./Ago. 2019 
fundamental não será capaz de sanar, como um passe de mágica, o estado de coisas inconstitucional $^{35}$.

O terceiro exemplo impende a análise conjunta de dois casos concretos e uma ação direta de inconstitucionalidade. Em maio de 2016 o Ministro Teori Zavaski (AC 4.070, Rel. Min. Teori Zavaski, j. 21/10/2016) concedeu medida liminar para determinar o afastamento do então deputado Eduardo Cunha da presidência da Casa e de seu mandato eletivo, por ocasião de desdobramentos de investigações da Operação Lava Jato. Em seguida, a medida liminar foi referendada pelo plenário de forma unânime. Um dos fundamentos da decisão foi de que o réu estaria usando o seu cargo político para atrapalhar as investigações tanto da ação em que já era réu, quanto de outros procedimentos. Ressalvou-se na decisão que a medida liminar não se tratava de um juízo definitivo de culpa e que mesmo não prevista expressamente na Constituição se mostrava extremamente necessária, em razão de tratar-se de caso extraordinário. Estando afastado de suas funções parlamentares, o ex presidente da Câmara dos Deputados teve seu mandato cassado em 12 de setembro de 2016, perdendo assim o foro por prerrogativa de função. Em outubro de 2016 Eduardo Cunha viria a ser preso por decisão da Justiça Federal da $4^{\text {a }}$ Região, com a posterior condenação em $1^{\mathrm{a}}$ e $2^{\mathrm{a}}$ instâncias.

Pouco mais de um ano apósessa decisão, o Plenário do Supremo Tribunal se deparou com a necessidade de analisar novamente um caso de afastamento de congressista, por suposta prática de ilícitos penais no exercício do mandato (AC 4.327, Rel. Min. Marco Aurélio, j. 27/10/2017). Em 26 de setembro de 2017 a 1 ${ }^{\text {a }}$ Turma do STF, em coerência com a decisão sobre o afastamento de Eduardo Cunha, decidiu, por maioria de votos,pelo afastamento do Senador Aécio Neves de seu mandato, bem como do cumprimento de medidas restritivas de direitos, como por exemplo, o recolhimento domiciliar noturno, dentre outras. O caso se referia àdenúnciado Procurador Geral da Repúblicapor suposta prática dos crimes de corrupção passiva e de obstrução de investigação de infração penal relacionada à organização criminosa. O detalhe é que outros três supostos coautores já se encontravam em prisão domiciliar, tendo em vista a gravidade dos fatos e evidências até então apurados.

Poucos dias após essa decisão foi pautada para julgamento a ADIn 5.526, na qual, em síntese, alguns partidos políticos com representação no Congresso requeriam que fosse conferida interpretação conforme à Constituição dos artigos 312 e 319 do CPP, no sentido de que a aplicação das medidas cautelares ali previstas a membros do Poder Legislativo, detentores de imunidades parlamentares formais, deveria ser submetida à apreciação da Casa Legislativa da qual o parlamentar é membro, no prazo de 24 horas, para que os demais membros pudessem deliberar sobre as medidas que implicassem em um afastamento do exercício das funções parlamentares.

Evidente que, apesar de ter sido um pedido formulado em controle abstrato, a ação possuía uma relevância fundamental para a autoridade do julgamento do próprio STF sobre o afastamento do Senador Aécio Neves. O ponto curioso é que pouco antes do julgamento foi noticiado pela imprensa a possibilidade de ataques institucionais por parte do Senado ao STF caso a decisão fosse desfavorável aos Congressistas, ainda que não haja qualquer indício de que tais declarações tenham tido alguma repercussão ou relação com o resultado final ${ }^{36}$. Sendo assim, no dia 11 de outubro de 2017 o Plenário do Supremo Tribunal Federal reapreciou,em sede de controle abstrato, matéria que já havia sido decidida em desfavor de parlamentares e, por uma apertada maioria,fixou que:(i) o Poder Judiciário teria competência para impor a parlamentares as medidas cautelares do art. 319 do CPP, (ii) mas que a Casa Legislativa respectiva teria a

\footnotetext{
${ }^{35}$ Esclareça-se que não se está aqui querendo dizer que a decisão foi de alguma forma ruim. Apenas deve-se deixar registrado que em termos de demandas estruturais é ilusório se orientar sob a lógica da Supremacia Judicial.

${ }^{36}$ Nesse sentido confira-se as seguintes notícias: <http://politica.estadao.com.br/noticias/geral,senado-desafia-stf-e-

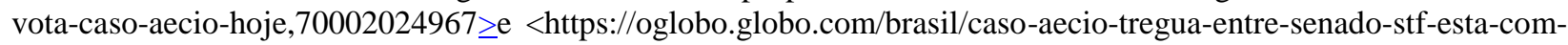
dias-contados-21920342 $\geq$. Acesso em 30.10.2017.
}

Revista de Direito Brasileira | Florianópolis, SC | v. 23 | n. 9 | p.147-171 |Mai./Ago. 2019 
competência de apreciar medidas cautelares que, direta ou indiretamente, impossibilitem o exercício regular de mandato parlamentar, na forma do art. $53, \S 2^{\circ}$ da $\mathrm{CF}^{37}$. Diante dessa decisão, no dia 17 de outubro de 2017, o Senado Federal decidiu por cassar as medidas restritivas de direitos e o afastamento do mandato impostas aoSenador Aécio Neves.

Antes de se querer realizar qualquer espécie de juízo de valor sobre eventual acerto ou equívoco do conteúdo das decisões acima narradas, o que se pretende demonstrar é a fragilidade que a "Supremacia Judicial" vai sempre estar assentada. Em um Estado de Democrático de Direito as Supremas Cortes ou Cortes Constitucionais não podem ser vistas como órgãos autistas. Ao contrário, conforme se mostrou brevemente nesta seção, a interação será sempre natural e necessária, principalmenteem casos que envolvam interesses políticos e institucionais dos demais Poderes - ou mesmo interesses da própria magistratura ${ }^{38}$. Algumas vezes, por variadas razões, os membros da Suprema Corte precisarão até mesmo adotar uma postura estratégica ${ }^{39}$ ou pragmática, seja para que suas decisões sejam cumpridas, seja para evitar alguma forma de ataque institucional iminente.

\subsection{A doutrina dos diálogos constitucionais}

Sem qualquer pretensão exaustiva, cabe analisar neste tópico alguns aspectos sobre a doutrina dos diálogos constitucionais. Os estudos a respeito dos diálogos constitucionais se colocam no âmago das discussões sobre quem tem ou quem deve ter a última palavra sobre a interpretação da Constituição e, de certa forma, a doutrina contrasta com os modelos que explicam o fenômeno segundo uma concepção de supremacia judicial ou de supremacia parlamentar.

Em síntese, a tese parte da possibilidade de que, em face de determinada decisão judicial, especialmente em sede de interpretação e aplicação da Constituição, os Poderes Executivo e Legislativopossam eventualmente contar com mecanismos para manter a discussão em aberto - ou até mesmo reabri-la - se assim se demonstrar conveniente ou oportuno. Ou seja, tais mecanismos permitem que se estabeleça um efetivo diálogo entre os Poderes democraticamente eleitos e o Judiciário, onde cada qual poderia contribuir com a sua respectiva capacidade institucional para a produção da melhor decisão possível ${ }^{40}$. A partir de então, pode-se dizer que essa realidade dialógicaevidencia tanto uma preocupação em termos de equilíbrio, harmonia e controles recíprocos na Separação de Poderes, quanto uma preocupação de ordem democrática, uma vez que a interação entre Poderes pode evitar que eventuais decisões equivocadas não se tornem imutáveis até o momento de uma superação de jurisprudência ${ }^{41}$.

\footnotetext{
${ }^{37}$ É de se destacar que até o momento de edição final deste trabalho essa decisão ainda não haviasido publicada.

${ }^{38}$ MARSHALL, Willian P.. Conservatives and the seven sins of judicial activism. In: University of Colorado Law Review, v. 73, 2002, p. 280-308.

39 "O modelo estratégico constitui o terceiro modelo referenciado pela literatura tradicional norte-americana sobre comportamento judicial. Ele é na verdade, espécie de um critério mais amplo de compreensão do processo decisório, o critério institucional. É, ainda, compatível, em parte, com as ideias do modelo ideológico, já que reconhece que os magistrados não são agentes neutros e que buscam projetar suas preferências pessoais sobre suas decisões, de forma a influenciar o conteúdo do direito. O que distingue o modelo estratégico do modelo ideológico é a forma pela qual se acredita que tal fim será atingido. O modelo ideológico confia que os juízes simplesmente votarão conforme suas conviç̧ões. O modelo estratégico aposta em uma atuação mais complexa”. (MELLO, Patrícia Perrone Campos. Nos bastidores do Supremo Tribunal Federal. - Rio de Janeiro: Forense, 2015, p. 152). Sobre o tema v. SEGAL, Jefrrey. Judicial Behaviour. New York: Oxford University Press, 2008.

${ }^{40}$ BRANDÃO, Rodrigo. Supremacia judicial versus diálogos constitucionais: a quem cabe a última palavra sobre o sentido da Constituição?. Op. cit., p. 336-338.

${ }^{41}$ Nesse ponto, merece transcrição a lição de Rodrigo Brandão: "Por outro lado, a difusão do entendimento de que a última palavra na interpretação constitucional é do Judiciário gera um desengajamento dos demais "poderes" e atores privados no processo de interpretação constitucional. Tal perspectiva juriscêntrica, somada à supremacia judicial em sentido material - segundo a qual a interpretação constitucional da Suprema Corte é extremamente difícil de ser

Revista de Direito Brasileira | Florianópolis, SC | v. 23 | n. 9 | p. 147-171 |Mai./Ago. 2019
} 
No interior desse debate, merecem destaque os mecanismos de superação normativa das decisões judiciais. Aqui especificamente refere-se a leis ou atos normativos com força de lei ou Emendas Constitucionais. Obviamente a viabilidade, a frequência e a intensidade do manejo a tais recursos dialógicos em um ordenamento constitucional e democrático demandam análises contextuais. Assim, por exemplo, em determinados ordenamentos jurídicos, pode ser aceitável, em caso de lei declarada inconstitucional pela Suprema Corte, que o Parlamento, caso deseje estabelecer um diálogo sobre a matéria, edite nova lei com conteúdo similar em pontos centrais ${ }^{42}$. Outra hipótese, talvez menos controvertida,considerando a mesma hipótese de declaração de inconstitucionalidade de lei ou ato normativo, é que o Poder Legislativo através do exercício do Poder Constituinte Derivado, edite Emendas Constitucionais superadoras de decisões da Suprema Corte.Nesse aspecto, existem alguns exemplos concretos ocorridos no Brasil ${ }^{43}$ e no direito comparado $^{44}$, em que efetivamente foi estabelecida uma interação entre a decisão judicial e as decisões políticas e normativas ou, ao menos, foi reconhecida a possibilidade de emprego de soluções dialógicas ${ }^{45}$.

No Brasil, um campo bastante promissor para a adoção de soluções dialógicas é o concernente à efetivação dos direitos sociais. Por um lado, o Constituinte de 1988 alçou os direitos sociais à condição de direitos fundamentais, o que sem dúvida alguma torna legítima a intervenção do Judiciário para a sua devida proteção. Por outro lado, todavia, é de se reconhecer que a promoção dos direitos sociais estará em grande medida associada à formulação de políticas públicas, que é função precípua dos Poderes eleitos democraticamente, além, é claro, de haver sempre o argumento da reserva do possível no tocante a sua efetivação.

Cite-se, como exemplo, a judicialização da saúde no Brasil. Uma crítica recorrente é de que demandas individuais pleiteando procedimentos médicos ou o fornecimento de medicamentos e tratamentos acabam impactando negativamente o orçamento e prejudicando a própria formulação da política pública. Mas não somente. Há também o argumento recorrente de que o Poder Judiciário não teria a capacidade institucional para enxergar os efeitos de suas

revertida - causa problemas de responsividade popular, sobretudo em um contexto de sensível judicialização da política. Explica-se: se virtualmente todas as questões políticas relevantes são judicializadas, a enorme dificuldade da superação das decisões da Suprema Corte torna o órgão de cúpula do Judiciário uma instituição "desviante" em um sistema democrático, pois irá dirimir um grande número de questões politicamente relevantes em relação às quais o povo não terá mecanismo efetivo de correção". (BRANDÃO, Rodrigo. Supremacia judicial versus diálogos constitucionais: a quem cabe a última palavra sobre o sentido da Constituição?.Op. cit., p. 344).

42 As lei ordinárias reeditadas com o conteúdo idêntico ao de uma lei declarada inconstitucional são conhecidas como "laws in your face". O presente trabalho não adota a posição de que a o diálogo por meio de leis ordinárias necessariamente se daria através das "laws in your face", que mais se assemelham a uma guerra de gritos entre os Poderes. É possível vislumbrar um meio termo, em que o Parlamento realiza alterações pontuais, reabrindo o diálogo com o Judiciário, com vistas à tomada da melhor decisão. É certo que, diante dessa hipótese, o Judiciário pode novamente, se for o caso, se orientar pela declaração de inconstitucionalidade da nova lei. Uma das vantagens de se admitir a reabertura do diálogo por meio de leis ordinárias é evitar que apenas através de supermaiorias eventual decisão da Suprema Corte tida como equivocada pudesse ser revista. Nesse sentido v. BRANDÃO, Rodrigo. Supremacia judicial versus diálogos constitucionais: a quem cabe a última palavra sobre o sentido da Constituição? Op. cit., p . 371-384.

${ }^{43}$ Nesse sentido,remete-se o leitor à nota de rodapé de número 29 do presente trabalho.

${ }^{44}$ Para o enfoque da matéria em outros ordenamentos jurídicos consultar: HOGG, Peter W.; BUSHELL, Alisson A.. El diálogo de la Carta entre los Tribunales y las Legislaturas (o quizá la Carta de Derechos no sea algo tan malo depués de todo); BERGALLO, Paola. La causa Mendoza: uma experiência de judicialización cooperativa sobre derecho a la salud; GARAVITO, César Rodriguez. El activism dialógico y el impacto de los fallos sobre derechos sociales. In: GARGARELLA, Roberto. Por uma justicia constitucional dialógica: el Poder Judicial como promotor de la deliberación democrática. Buenos Aires: Siglo Veitiuno Editores, 2014.

${ }^{45}$ Parece ter sido esse o posicionamento adotado pelo STF no julgamento da ADIN 4.650, cujo objeto de discussão foi o financiamento privado de campanhas eleitorais, em que alguns Ministros, especialmente o relator, Ministro Luiz Fux, admitiram que a decisão poderia se constituir como importante recurso dialógico para fins de concretização da reforma política.

Revista de Direito Brasileira | Florianópolis, SC | v. 23 | n. 9 | p.147-171 |Mai./Ago. 2019 
decisões em uma perspectiva mais ampla e sistêmica, uma vezque cada juiz ficaria adstrito a tão somente avaliar os efeitos dos casos concretos que julga.

Nesse aspecto, é bastante interessante a proposta formulada pelo Ministro Roberto Barroso em seu voto-vista no RE 566.471. Basicamente, trata-se de Recurso Extraordinário com Repercussão Geral em que se discute os limites da judicialização da saúde. NeleBarroso se preocupa em traçar parâmetros seguros para atuação judicial na matéria. A utilização de diálogos é bem destacada em alguns trechos de seu voto, no qual pode-se destacar o seguinte: " $O$ conhecimento técnico limitado dos magistrados sobre as tecnologias em saúde exige o emprego de fórmulas dialógicas, que lhes permitam colher as informações necessárias para a tomada de decisão $o^{46 " .}$.

Além de demandas relativas à discussão e efetivação de direitos sociais,outro campo em que o uso de técnicas decisórias dialógicas pode se evidenciar bastante promissor é o do monitoramento de políticas públicas de uma forma mais ampla ${ }^{47}$.Uma alternativa que parece ser muito mais produtiva do que a reformulação ou redesenho de políticas públicas por parte do Poder Judiciário seria a realizaçãode controle sobre motivações, metas e transparência, como por exemplo, com a exigência de apresentação de relatórios ou pareceres periódicos por parte dos formuladores da política pública.

Por fim é importante destacar que ignorar a ocorrência das interações interinstitucionais em um sistema que preza pela separação, mas ao mesmo tempo pelo equilíbrio entre os poderes, para se afirmar a vigência de uma pretensa supremacia judicial pode levar a resultados não desejáveis para o Estado de Direito. Caso não sejam admitidas "válvulas de escape" para a superação de decisões equivocadas sob o ponto de vista democrático, os poderes políticos tenderão a atuar através de formas nem um pouco republicanas para que as suas vozes sejam ouvidas dentro da seara da interpretação constitucional. Nesse quesito, podemos citar o não cumprimento de decisões judicias, os cortes orçamentários ao Judiciário, a alteração das competências jurisdicionais, a instauração de processos de impeachment contra Ministros da Suprema Corte e a alteração no número de membros das Cortes Superiores ${ }^{48}$.E é de se ressaltar quetais expedientesse assemelhariam mais a uma guerra de gritos do quepropriamente um diálogo 49 .

\section{O SUPREMO E AS COMPETÊNCIAS MONOCRÁTICAS}

\subsection{Breve análise das competências do Supremo Tribunal Federal: competências superlativas?}

A análise das competências monocráticas impende uma análise sobre as próprias competências jurisdicionais do Supremo Tribunal Federal, de forma global, que estão enumeradas nos incisos e alíneas do artigo 102 da Constituição Federal. É certo que o enfoque mais acurado sobre as competências do Supremo Tribunal Federal demandaria um estudo próprio e específico. No entanto, é importante ter em mente a amplitude de tais competências para se compreender as razões que justificam a ampliação daatuação jurisdicional na forma monocrática pela Corte. O dispositivo constitucional acima referido é subdividido em competências

\footnotetext{
${ }^{46}$ Voto Vista do Min. Roberto Barroso no RE 566.471, p. 28.

${ }^{47}$ BARCELLOS, Ana Paula de. Sanitation rights, public law litigation, and inequality: a case study from Brazil. In: Health and human rights journal, number 2, volume 16, 2014, p. 43.

${ }^{4}$ FISHER, Louis. Constitutional dialogues - Interpretation as a politic process. Oxford: Princeton University Press, 1988, p. 200-230.

${ }^{49}$ BRANDÃO, Rodrigo. Supremacia judicial versus diálogos constitucionais: a quem cabe a última palavra sobre o sentido da Constituição?. Op. cit., p. 371-384.

Revista de Direito Brasileira | Florianópolis, SC | v. 23 | n. 9 | p. 147-171 |Mai./Ago. 2019
} 
originárias, competências para o julgamento de recursos ordinários e competências para o julgamento de recursos extraordinários, totalizando vinte e dois incisos, enumerando as ações e recursos pertinentes e suas hipóteses de cabimento.

Nesse aspecto, pode-se afirmar que as competências originárias, isto é, aquelas que são propostas de forma inicial e direta na mais alta Corte do país, abrangem a análise de ações de controle abstrato de constitucionalidade (ADIN, ADC, ADPF e ADIN-O), ações penais ou ações que tenham como objeto crime de responsabilidade contra certas autoridades detentoras de foro por prerrogativa de função, ações originárias que denotem algum conflito federativo ou internacional, ações constitucionais (HC, MS, MI e HD) contra atos de certas autoridades ou tribunais ou em favor de outros indivíduos enumerados, extradições, reclamações para preservação da autoridade de seus julgados, revisões criminais e ações rescisórias, ações que denotem o interesse de toda magistratura ou em que mais da metade dos membros de um tribunal estejam impedidos ou interessados, conflitos de competência, ações contra o CNJ e o CNMP e a execução de sentenças de sua competência originária.

Por sua vez, as competências recursais, ainda que previstas de formaum pouco mais enxutas, abrangem hipóteses que propiciam, igualmente, uma enxurrada de recursos que são submetidos ao crivo do STF. Assim, em recurso ordinário devem ser analisados aqueles oriundos de ações constitucionais (HC, MS, HD, MI) julgadas em única instância pelos tribunais superiores, se a decisão foi denegatória e os oriundos do julgamento de crimes políticos. Por outro lado, o Recurso Extraordinário, em última análise, é o recurso que tem como fito a preservação da Supremacia da Constituição - a partir da constatação de sua ofensa direta ${ }^{50}$ - ao realizarexame de matérias de índole constitucional,sendo cabíveis em quatro hipóteses ${ }^{51}$.Em razão de a discussão dos Recursos Extraordinários ser oriunda de casos concretos e pela característica extremamente analítica da Constituição Federal de 1988, potencialmente quase todas as demandas que fossem fundamentadas em dispositivos constitucionais poderiam ter os seus desfechos definidos pelo Supremo Tribunal Federal.

Percebe-se, desta forma, o que anteriormente foi enunciado: a Constituição Federal de 1988 conferiu competências superlativas ao STF, podendo-se afirmar que fugiu até mesmo ao nível do razoável. Se por um lado, o Tribunal torna-se excessivamente poderoso, na medida em que "quase tudo" passa (ou pode passar) pelo seu crivo, por outro lado, é cristalino que, pragmaticamente, o funcionamento da Corte, que exerce simultaneamente os papéis de jurisdição constitucional e de última instância da Justiça brasileira, fica inviabilizado. E isso porque torna-se humanamente inviávelque os seus Ministros respondam a todas as demandas, a partir da noção de duração razoável do processo e do nível de reflexão e deliberação que cada caso exige.

No entanto, as competências do STF não param na Constituição. Algumas leis específicas preveem outras competências, especialmente recursais. Assim, por exemplo, a lei 9.868/99, nos artigos $4^{\circ}$, PU, 12-C, PU e 15, PU,prevê a competência para o STF julgar agravo da inadmissão da ADIn, da ADIn-O e da ADC, respectivamente. A lei 9.882/99 prevê em seu artigo $4^{\circ}, \S 2^{\circ}$ o agravo da inadmissão da ADPF. O CPC, igualmente, prevê competências genéricas para o julgamento de agravos de instrumento, agravos internos e embargos de declaração, que também se aplicam ao STF. Além disso, é certo que, ainda que não seja caso de competência propriamente dita do Supremo Tribunal Federal, determinada questão pode eventualmente ser analisada em razão de sua relevância social, econômica ou política a partir de seu recebimento como direito de petição.

A partir dessa visão geral sobre as competências do Supremo, é preciso destacar de forma singela que competências monocráticas podem ser definidas como aquelas, em que em um órgão decisório colegiado, um de seus membros, denominado relator, analise e julgue, per se, e

\footnotetext{
${ }^{50}$ RODRIGUES, Marco Antônio. Manual dos recursos, ação rescisória e reclamação. - 1. ed. - São Paulo: Atlas, 2017, p. 225.

${ }^{51}$ RODRIGUES, Marco Antônio. Manual dos recursos, ação rescisória e reclamação. Op. Cit., p. 227-236.
}

Revista de Direito Brasileira | Florianópolis, SC | v. 23 | n. 9 | p.147-171 |Mai./Ago. 2019 
sem a participação dos demais a demanda que lhe foi submetida, por uma questão de economia ou eficiência processual ${ }^{52}$. Obviamente que se se trata de um órgão colegiado,o mínimo que se espera é a existência de alguma modalidade de recurso que permita a reanálise coletiva da demanda, o que normalmente é realizado por meio de agravos internos, conforme dispõe o art. 1.021 do CPC.Portanto, deve-se ressaltar que as razões para a existência de competências monocráticas se ligam à necessidade de celeridade, eficiência e efetividade da prestação jurisdicional ${ }^{53}$, ainda mais em um órgão com competências superlativas.

Deve-se também destacar que o STF é essencialmente um órgão decisório colegiado deliberativo. No entanto, como é intuitivo, as competências superlativas não permitem que os onze Ministros se reúnam e analisem todas as questões que são submetidas à Corte. Se assim fosse, o funcionamento do tribunal certamente seria inviabilizado. Assim, o exercício de competências monocráticas acaba sendo essencialmente e pragmaticamente uma questão de como o STF se organiza internamente na tentativa de realizar a sua prestação jurisdicional de forma mais célere, eficiente e efetiva.

\subsection{Distorções Democráticas e representativas?}

Talvez a maior das críticas que a atuação de uma Suprema Corte vem a receber seja a respeito de um suposto déficit democrático. Essa crítica é exposta a partir da noção de que juízes não eleitos pelo povo, algumas vezes vinculados a setores elitistas da sociedade, invalidam leis e atos normativos aprovados pelos representantes eleitos democraticamente pelo povo. É a chamada dificuldade contramajoritária ${ }^{54}$.

Em uma sociedade cada vez mais complexa, essa assertiva merece ser problematizada e alguns trabalhos acadêmicos demonstraram que muitas vezes ela não é tão verdadeira quanto parece $^{55}$. Em primeiro lugar, o ideal de que os governantes eleitos pelo povo correspondem à vontade deste, pode, em alguns contextos, parecer um tanto quanto falacioso. O que se verifica em países como o Brasil é uma verdadeira crise da representatividade político partidária. $\mathrm{O}$ sistema políticopropicia que sejam eleitos, majoritariamente, aqueles que conseguem angariar os valores mais vultosos de financiamento de campanha ${ }^{56}$. Disso advém a primeira constatação de

\footnotetext{
52 “Os Tribunais são órgãos colegiados, constituídos por vários juízes, norma esta que se extrai da Constituição Federal. (...) Entretanto, não será possível que todos os membros de um órgão do tribunal sejam reesposáveis pela condução conjunta dos processos, sob pena de violação da eficiência, nos termos do art. 8 . $^{\circ}$ do CPC. Isso representaria uma repetição desnecessária de trabalho. Assim, previu o Código de Processo Civil a figura do relator, que será, entre os integrantes do órgão jurisdicional, o julgador competente para cumprir as atribuições previstas no art. 932. O relator é um porta-voz avançado do colegiado, atuando em nome deste e em prol da eficiência processual, como mencionado". (RODRIGUES, Marco Antônio. Manual dos recursos, ação rescisória e reclamação. Op., cit., p. 111-112).

${ }^{53}$ Por exemplo, no STF muitos dos Recursos Extraordinários analisados e inadmitidos o são de forma monocrática pelos seus respectivos relatores quando estes verificam ausência de prequestionamento ou de repercussão geral ou ainda quando houver revolvimento de matéria fática já discutida em instâncias inferiores. É óbvio que seria impraticável que o Plenário ou as Turmas realizassem o juízo de admissibilidadede todos esses recursos que são inadmitidos pelos relatores monocraticamente, caso contrário, certamente, incorrer-se-ia em prejuízo demasiado na prestação jurisdicional da Corte de uma forma ampla.

${ }^{54}$ BICKEL, Alexander M. The least dangerous branch: The Supreme Court at the bar of Politics. Second Edition. New Haven and London: Yale University Press, 1986, p. 16.

${ }^{55}$ Nesse sentido, v.: BARROSO, Luís Roberto. A razão sem voto: o Supremo Tribunal Federal e o governo da maioria. In: Revista Brasileira de Políticas Públicas, Brasília, v. 5, Número Especial, 2015; PEREIRA, Jane Reis. Representação democrática do Judiciário: reflexões preliminares sobre os riscos e dilemas de uma ideia em ascensão. In: Revista Juris Poiesis vol 17, 2014.

56 Sobre o tema veja: SARMENTO, Daniel; OSÓRIO, Aline. Uma mistura tóxica: política, dinheiro e o financiamento das eleições. Disponível em: <http://www.migalhas.com.br/arquivos/2014/1/art20140130-01.pdf>. Acesso 03.10.2017.
}

Revista de Direito Brasileira | Florianópolis, SC | v. 23 | n. 9 | p. 147-171 |Mai./Ago. 2019 
que os políticos eleitos vão, majoritariamente, prestar contas a certos grupos de interesse e não necessariamente ao seu eleitorado.

Em segundo lugar, o sistema que se convencionou denominar de presidencialismo de coalização ${ }^{57}$ põe em primeiro plano a necessidade de concertos políticos - que em alguns casos podem ser entendidos como verdadeiras trocas de favores políticos - para que se possa alcançar o ideal da governabilidade. Não é incomum, nesse aspecto, que as negociações travadas entre Executivo e Legislativo cheguem a soluçõesque não correspondem aos ideais de seus eleitores, da população em geral ou mesmo aqueles estampados nas bandeiras de seus respectivos partidos políticos $^{58}$.

Por outro lado, o Judiciário não necessariamente se constituirá como um Poder totalmente contramajoritário ${ }^{59}$. É certo se afirmar que, na maior parte das questões, as Supremas Cortes são deferentes às maiorias políticas. É dizer, apenas um número bastante reduzido apesar de bem notório - de decisões seria efetivamente contrária às vontades e decisões políticas dos Poderes majoritários. Haveria uma "cota" de decisões contramajoritárias que poderiam proferir sem o risco de sofrerem ataques institucionais.

Ademais, as Supremas Cortes também costumam se alinhar com a opinião pública $^{60}$.Apesar dessa interação ser muito complexa e seu delineamento completo fugir aos objetivos do presente trabalho, deve-se apenas considerar que a natural publicidade das decisões judiciais e a transmissão das sessões plenárias do STF por meio da TV justiça expõem o Tribunal às mídias e o tornam muito mais permeável à opinião pública em geral. Mais do que isso, é de se considerar que os Ministros não são pessoas desenraizadas. Muito pelo contrário, são indivíduos com diferentes formações humanísticas e profissionais, que frequentam círculos sociais e que, obviamente, leem jornais e revistas e acessam mídias eletrônicas. Esses aspectos moldam as opiniões e as convicções dos Ministros de diferentes formas e podem gerar certo tipo de responsividade judicial ao sentimento majoritário.

Por outro lado, é natural que, a partir das indesejáveis e recorrentes distorções do sistema político democrático do Brasil, a jurisdição constitucional acabe assumindo um papel representativo. Esse papel seria assumido pelas Supremas Cortes -constituídaspor juízes não eleitos pelo voto democrático - na medida em que conseguira ser mais representativa da vontade das maiorias,a partir, principalmente,das mencionadas distorções do sistema político eleitoral, que muitas vezes tolhem os representantes eleitosde corresponderemsatisfatoriamente às vontades majoritárias, conforme já assentado.

Além de outros aspectos, como por exemplo, a própria independência judicial do Poder Judiciário em contraposição às necessárias prestações de contasdos poderes eleitos ao eleitorado,

\footnotetext{
57 "O sistema político vigente no Brasil foi batizado por Sérgio Abranches, em 1988, de 'presidencialismo de coalização' e tem como principal característica eleger o presidente da República com mais votos do que seu partido recebe nas eleições para o Poder Legislativo, criando a necessidade de alianças políticas"(AVRITZER, Leonardo. Impasse da democracia no Brasil. - $3^{\mathrm{a}}$ ed. - Rio de Janeiro: Civilização Brasileira, 2016, p. 10).

${ }^{58}$ Nesse sistema de governo, para fins de estabilização política podem ser realizadas cessões de ministérios e nomeações para cargos de segundo escalão, por exemplo. (AVRITZER, Leonardo. Impasse da democracia no Brasil. Op. Cit., p. 11).

59 Esse papel contramajoritário no âmbito do Estado Democrático de Direito costuma ser aceito a partir da necessidade de resguardar os direitos fundamentais da interferência das maiorias eventuais e as próprias regras atinentes à democracia e à participação política. Luís Roberto Barroso, nesse sentido vai além e afirma que o Supremo Tribunal Federal - e as demais Supremas Cortes - exercem três papéis: o representativo, o contramajoritário e o iluminista. BARROSO, Luís Roberto. A razão sem voto: o Supremo Tribunal Federal e o governo da maioria. In: Revista Brasileira de Políticas Públicas, Brasília, v. 5, Número Especial, 2015, p. 36.

${ }^{60}$ Sobre o tema, v.: NOVELINO, Marcelo. O STF e a Opinião Pública. In: SARMENTO, Daniel. Jurisdição Constitucional e política. Rio de Janeiro: Forense, 2015; FRIEDMAN, Barry. The will of the people, how public opinion has influenced the supreme court and shaped the meaning of the constitution. New York: Farrar, Straus and Giroux, 2009.
} 
pode-se afirmar, assim como Barroso $^{61}$, que o papel representativo ganha força com a ideia de legitimidade discursiva ou argumentativa.Isso porque o Judiciário obrigatoriamente deve proferir suas decisões de forma motivada, se desincumbindo de um grande ônus argumentativo, a partir de um amplo debate. A fundamentação de decisões através de argumentos jurídicos sólidos, que encontram guarida na Constituição, também representaria uma forma de representação popular, na medida em que consiga convencer o auditório. Em suma, a função representativa envolveria a capacidade de o Judiciário, através de uma atuação argumentativa atender relevantes demandas que não foram capazes de ser atendidas pelas instâncias majoritárias.

Diante disso, pode-se afirmar que as tradicionais críticas associadas à dificuldade contramajoritária podem ser perfeitamente contornadas em um contexto de democracia deliberativa e de interação e diálogo institucional. Todavia, o exercício de competências monocráticas, em um sem número de decisões ${ }^{62}$, pela mais alta Corte do país, pode representar um refluxo das dificuldades contramajoritárias.

Isso porque para que sejam minimamente satisfeitas condições da democracia deliberativa, como facilmente se intui, é necessário que ocorra algum processo de deliberação. Uma decisão monocrática é proferida individualmente e, por mais correta e bem fundamentada que possa ser, perde em pluralismo. Ou seja,há uma redução na capacidade de se instaurarum processo deliberativo que abranja contraposição de visõesdivergentes e debates. Outro problema associado ao uso recorrente de competências monocráticas diz respeito à segurança jurídica, ponto que será abordado no tópico a seguir.

Obviamente, que poder-se-ia contra argumentar que as decisões monocráticas são tendencialmente provisórias, uma vez que podem vir a ser revistas pelos órgãos colegiados do Tribunal. No entanto, seria inverossímil a suposição de que todos os casos decididos monocraticamente por Ministros do Supremo Tribunal Federal serão revistos pelos órgãos colegiados competentes, ou mesmo que serão apreciados segundo uma lógica deliberativa. Ainda que algumas decisões monocráticas acabem de fato sendo revistas, os efeitos temporáriossuscitados podem ser negativos do ponto de vista democrático.

Cabe aqui descrever dois casos concretos ocorridos no Brasil. O primeiro trata-se da criação de quatro novos Tribunais Regionais Federais (ADIn 5.017, Rel. atual Min. Luiz Fux). Em junho de 2013, foi aprovada pelo Congresso Nacional a Emenda Constitucional $\mathrm{n}^{\mathbf{0}} 73$, que previa a criação de quatro novos Tribunais Regionais Federais, que se somariam aos cinco hoje existentes. A Associação Nacional dos Procuradores Federais (ANPAF) ingressou com uma ação direta de inconstitucionalidade questionando a constitucionalidade da referida Emenda Constitucional. Dentre os argumentos se alegou: vício de iniciativa, que mesmo em matéria de Emenda Constitucional seria do STF; a criação de um precedente perigoso que poderia afetar a independência judicial;a necessidade de reestruturação abrupta da carreira de advocacia pública; equestões orçamentárias, como por exemplo, a inexistência de dotação orçamentária impediria as mudanças necessárias dos advogados públicos para que eles pudessem defender os interesses da União nesses novos Tribunais. O caso foi apreciado em sede cautelar pelo então presidente do Supremo Tribunal Federal, Ministro Joaquim Barbosa, durante o recesso da Corte, no sentido de concessão da medida cautelar para suspender os efeitos da EC 73 e, por conseguinte, a criação dos novos Tribunais Regionais Federais, sob os argumentos de plausibilidade das alegações de

\footnotetext{
${ }^{61}$ BARROSO, Luís Roberto. A razão sem voto: o Supremo Tribunal Federal e o governo da maioria. Op. cit., p. 40.

${ }^{62}$ Para um estudo sobre as decisões monocráticas no STF até 31 de dezembro de 2013 v. HARTMANN, Ivar Alberto Martins; FERREIRA, Lívia da Silva Ferreira. "Ao Relator, Tudo: O Impacto Do Aumento Do Poder Do Ministro Relator No Supremo." Revista Opinião Jurídica (Fortaleza) 13, no. 17, 2015. Este trabalho aponta como conclusão que os Ministros do Supremo pareciam ter adotado como regra e não como exceção a prática das decisões monocráticas. Dentre os dados que merecem ser citados estão que entre 1992 e 2013, 93\% das decisões são tomados de forma individual, além do que desde 2009, as decisões de mérito colegiadas no controle difuso representam menos de $1 \%$ do total.
} 
enfraquecimento da independência judicial, ante o risco de um Poder interferir unilateralmente na estrutura de outro, além de entender ter se configurado o vício de iniciativa.

Merece destaque para os fins do presente trabalho o trecho final da decisão cautelar na ADI 5.017:

"Por fim, é bom que se diga que a suspensão temporária dos efeitos da EC 73/2013 é plenamente reversível. Estando sujeita ao referendo do Colegiado, a medida cautelar ora concedida poderá ser examinada em breve. Não haverá prejuízo, portanto, se o Plenário entender por sua cassação".

Ora, passados pouco mais de quatro anos desta decisão, a liminar sequer foi submetida ao Plenário da Corte $^{63}$. É dizer: a decisão monocrática e provisória de um único Ministro, por mais razoável e correta que fosse, foi capaz de suspender os efeitos de uma Emenda Constitucional, aprovada por um quórum de maioria qualificada, por tempo indeterminado. Talvez esse seja um caso inédito para qualquer Estado Democrático de Direito. É certo que poucos países admitem o controle de constitucionalidade sobre Emendas Constitucionais, tal qual o Brasil, haja vista se tratar de manifestação do Poder Constituinte Derivado. No entanto, mesmo naqueles em que tal controle é possível, evidente que o Judiciário deve possuir um nível de autocontenção maior do que para o mero controle de leis ordinárias ${ }^{64}$.

O segundo caso trata-se da decisão de afastamento do ex Presidente do Senado Federal, Renan Calheiros, em dezembro de 2016 (ADPF 402, Rel. Min. Marco Aurélio, j. 07/12/2016). O pedido de afastamento foi ajuizado pelo partido Rede Sustentabilidade, em sede de ADPF,uma vez que, a partir da decisão proferida no caso Eduardo Cunha, relatado acima,se assentou que réus em processos penais não poderiam estar na linha de substituição do presidente da República, por uma interpretação do art. $86, \S 1^{\circ}$ da CF. O partido político solicitou urgência em seu pedido de medida cautelar, haja vista a "plausibilidade do direito" e o fato de o então Presidente do Senado Federal estar respondendo "ação penal com trâmite no Supremo" 65 , que havia sido recebida em $1^{\circ}$ de dezembro (Inquérito 2.593, Rel. Min. Édson Facchin). Atendendo ao pedido de urgência, ante a ocorrência de fatos novos, o Ministro relator deferiu monocraticamente medida cautelar para afastar Renan Calheiros da presidência do Senado Federal, mas não de seu mandato, em 05 de dezembro de 2016. O detalhe é que a ADPF teve seu julgamento suspenso em razão de pedido de vista do Ministro Dias Tóffoli cerca de um mês antes, onde apesar da maioria formada não houve um pronunciamento final da Corte.

As consequências foram amplamente divulgadas pela mídia. Em contrariedade à decisão judicial, o Presidente do Senado Federal se recusou a receber a intimação do oficial de justiça, de modo que o seu afastamento não foi efetivado. Com efeito, não houve tempo para que tal decisão fosse tornada concreta: a liminar acabou sendo submetida ao Plenário do Supremo em 07 de

\footnotetext{
${ }^{63} \mathrm{Em} 2015$ já havia quemcriticasse a demora de submissão dessa decisão ao Plenário. Nesse sentido, v.: <https://jota.info/justica/liminar-que-barrou-criacao-de-trfs-completa-dois-anos-17072015>. Acesso em $17 / 10 / 2017$.

${ }^{64}$ BRANDÃO, Rodrigo. Supremacia judicial versus diálogos constitucionais: a quem cabe a última palavra sobre o sentido da Constituição?. Op., cit., p. 385-394.

${ }^{65}$ Para fins de esclarecimento da cronologia dos fatos é importante destacar que a ADPF havia sido proposta em 3 de Maio de 2016, quando na ocasião o deputado Eduardo Cunha ocupava o cargo de presidente da Câmara dos deputados. Ocorre que o julgamento da AC 4.070 foi realizado em um momento antes, através de liminar deferida pelo Ministro Teori Zavaski e referendada pelo Plenário, no sentido de afastar o presidente da Câmara dos Deputados de seu cargo e também do exercício de seu mandato, a partir de pedido formulado pelo PGR. Deste modo, o Ministro relator entendeu que a urgência suscitada pelo partido político Rede Sustentabilidade naquele momento não persistia. A ADPF voltou à pauta em 3 de Novembro de 2016, ocasião em que votaram 6 Ministros a favor dos argumentos suscitados na inicial. Formou-se assim maioria absoluta na tese de que Réu em ação penal não poderia ocupar cargo integrado à linha de sucessão do Presidente da República. No entanto, o julgamento foi interrompido pelo pedido de vista do Ministro Dias Tóffoli.
}

Revista de Direito Brasileira | Florianópolis, SC | v. 23 | n. 9 | p.147-171 |Mai./Ago. 2019 
dezembro de 2016, ocasião em que prevaleceu o entendimento de que réus de processos penais não poderiam,tão somente, ocupar o cargo de Presidente da República e, portanto, Renan Calheiros não chegou a ser afastado de seu mandato como Presidente do Senado Federal.

Os casos acima narrados são emblemáticos porque trazem a tona dois pontos especialmente delicados no exercício da jurisdição constitucional: o controle de Emendas Constitucionais e a "colisão" com autoridades democraticamente eleitas no exercício do poder político. Nesses casos específicos, de alguma forma, se acentua a dificuldade contramajoritária do Poder Judiciário. Repita-se os termos acima afirmados: essa dificuldade pode (e será) superada a partir da consideração da função representativa da jurisdição constitucional, mas para tanto é preciso que a Suprema Corte conte com elevado grau de legitimidade, que pode ser suprida a partir da atuação colegiada.

Todavia, aqui se parte da tese de que o exercício exacerbado de competências monocráticas (especialmente em decisões liminares) fragiliza eventual função representativa da Suprema Corte. Mais do que isso, deve-se se assentar que todas as matérias que sejam consideradaspoliticamente ou institucionalmente relevantesnão podem(ou não devem) ser decididas de forma monocrática. $\mathrm{O}$ afastamento de uma autoridade democraticamente eleita, de um cargo de Presidência ou mesmo do seu mandato eletivo, é uma situação muito grave do ponto de vista institucional para ser decidida por apenas um Ministro. Igualmente suspender monocraticamente os efeitos de uma Emenda Constitucional parece ser uma decisão institucionalmente muito severa do ponto de vista democrático ${ }^{66}$.

E isso em razão, reafirme-se, do fato de que o Supremo Tribunal Federal é um órgão colegiado. Como tal, o modelo decisório que melhor legitima a sua atuação é o modelo deliberativo ${ }^{67}$. O julgamento aqui se dá atravésda formação de um consenso entre os membros do Tribunal, a partir da exposição argumentativa das diferentes visões e opiniões dos membros que compõem a Corte. Ao final, a decisão prolatada estará mais próxima da visão da Corte como instituição e menos da opinião de uma eventual maioria ou de algum membro da Corte que tenha conduzido mais ativamente o julgamento ${ }^{68}$. Essa característica caso associada com a existência de uma efetiva pluralidade dos membros da Corte, isto é, que provenham de distintos grupos sociais e institucionais, tende, potencialmente, a produzir melhores decisões do ponto de vista deliberativo e democrático.

\subsection{As "onze ilhas" e a insegurança jurídica}

Em primeiro lugar, o uso indiscriminado de competências monocráticas acaba acentuando o que se convencionou chamar de fenômeno das "onze ilhas" ${ }^{69}$ ". Suscintamente se refere ao fato de que o Supremo Tribunal Federal, como órgão colegiado, seria composto de

\footnotetext{
${ }^{66}$ De um lado há o argumento legitimador do controle de constitucionalidade de Emendas Constitucionais no Brasil, com o qual se concorda, de que o grau de "detalhismo" da CF88 traz como consequência que muitas matérias de política ordinária são veiculadas via Emendas Constitucionais e que não seria por isso legítimo imuniza-las ao controle de constitucionalidade, tendo em vista o parâmetro constitucional das cláusulas pétreas. De outro lado, poder-se-ia argumentar por uma maior autocontenção judicial na matéria, uma vez que o controle de constitucionalidade sobre Emendas Constitucionais poderia convolar o Poder Judiciário em Poder Constituinte.

${ }^{67} \mathrm{O}$ modelo deliberativo é aquele no qual, através da argumentação e busca do consenso entre os membros, propicia a formação de um resultado coletivo. Além do modelo deliberativo, podem ser citados o modelo agregativo, externo, interno, em série e per curiam.Sobre o tema v.: MELLO, Patrícia Perrone Campos. Nos bastidores do Supremo Tribunal Federal. Op., cit., p. 172.

${ }^{68}$ É evidente que pode haver problemas nessa adoção. Por exemplo, normalmente o modelo deliberativo está associado ao modelo de decisão interna, isto é, aquela produzida a portas fechadas, o que sem dúvida pode produzir decisões dissonantes do interesse público ou com baixa accountability. MELLO, Patrícia Perrone Campos. Nos bastidores do Supremo Tribunal Federal. Op., cit., p. 173-175.

${ }^{69}$ Sobre o tema v.: <https://www.jota.info/artigos/onze-ilhas-supremas-ou-ministros-invisiveis-o-que-o-stf-reservapara-2016-04022016 $\geq$ e <http://www1.folha.uol.com.br/fsp/opiniao/fz0102201008.htm $\geq$. Acesso em 25.08.2017.
}

Revista de Direito Brasileira | Florianópolis, SC | v. 23 | n. 9 | p. 147-171 |Mai./Ago. 2019 
"onze Supremos" distintos. Ou seja, cada um de seus Ministros atuaria e decidiria de forma isolada e individualista ou a partir de um modelo de decisão meramente agregativo ${ }^{70}$.

Obviamente que a crítica se expande para além da atuação monocrática de cada Ministro, alcançando até mesmo às sessões plenárias, no sentido de que em muitas delas não haveria uma verdadeira deliberação no processo decisório, mas uma mera soma de votos convergentes. Todavia, a crítica das "onze ilhas"evidencia umefeito especialmentenegativo no exercício das competências monocráticas: a pouca vinculação do Tribunal aos seus próprios precedentes, visto que os Ministros tendem a decidir mais conforme suas convicções pessoais do que com base nas "convicções" da Corte.

Além disso, o modelo agregativo de decisões do Plenário - que evidencia uma postura mais individualista da Corte - traz em certos casos uma dificuldade de compreensão do significado de um precedente. De alguma forma foi mais ou menos o que sucedeu por ocasião do julgamento da ADPF 130, na qual se declarou a não recepção in totum da lei de imprensa. As razões apresentadas pelos ministros foram tão variadas que em sede de reclamação constitucional (Rcl 9428, Rel. Min. Cezar Peluso, j. 25/06/2010), apreciada pelo Plenário da Corte, o Ministro relator Cézar Peluso reconheceu que o pedido do reclamante se fundava em uma visão particular do voto do relator e não no posicionamento da Corte.

Isso apenas evidencia que a atuação monocrática e individualista dos membros de uma Suprema Corte, caso exercida de forma acrítica e sem cautela, não produz bons resultados. Além do mais, pode-se afirmar que a baixa vinculação aos próprios precedentesgerainsegurança jurídica nos jurisdicionados. A partir do momento em que cada Ministro decide isoladamente, conforme a sua própria convicção, ignorando os entendimentos fixados pelos Colegiados, pode provocar nas partes a sensação da existência de uma "loteria do juiz natural". Nesse ponto, pode, inclusive, ocorrer um fenômeno curioso: o de jurisdicionados e até mesmo aSuprema Corte se depararem com casos em que não se consiga efetivamente delinear o real significado de um precedente relacionado com a matéria a ser decidida. Sendo assim, tal matéria deverá ser rediscutida para que haja efetivamente segurança jurídica. Consequentemente a Corte tende a perder em eficiência, celeridade e ganhar em carga de trabalho.

Por fim, é de se afirmar que a expansão de competências monocráticasda Corte possibilita a atuação facciosa e não republicana de certos Ministros. Ainda que posteriormente o Plenário possa cassar decisões monocráticas ou cautelares populistas ou decisionistas, é certo que por algum lapso de tempo tais decisões terão repercussões práticas no mundo real, o que pode causar danos irreparáveis. E isso porque não haveria constrangimentos internos ${ }^{71}$ para que os Ministros assumissem posturas autocontidas. Em questões politicamente salientes ou institucionalmente relevantes o maior freio para o decisionismo tende a ser o modelo colegiado e deliberativo de decisão.

\subsection{Proposições}

Inicialmente deve-se afirmar que aqui não se está a defender a extinção de competências monocráticas e tê-las como as grandes responsáveis por todas as mazelas imagináveis para o nosso regime democrático. A circunstância de seu manejo até a presente datater sido excessivo e ter gerado alguns dos problemas acima suscitados, não obsta que sereconheça a sua imperiosa

\footnotetext{
${ }^{70} \mathrm{O}$ modelo agregativo de decisão é aquele por meio do qual o julgamento é formado pelo cômputo dos votos dos juízes, manifestados individualmente, onde não busca-se produzir um entendimento comum. MELLO, Patrícia Perrone Campos. Nos bastidores do Supremo Tribunal Federal. Op., cit., p. 173.

${ }^{71}$ Os Ministros do STF não se submetem disciplinarmente ao CNJ, apenas à própria Corte Suprema. Ademais, o controle externo sobre o STF ocorre através da constatação de crime de responsabilidade e processamento de impeachment perante o Senado Federal. No entanto, é de se reconhecer que, nos processos de impeachment, o juízo de admissibilidade e de mérito acabam sendo, essencialmente, juízos políticos e o seu manejo é pouco usual em democracias consolidadas.
} 
necessidade prática. Os casos em que já há jurisprudência firme e consolidada da Corte e aqueles que não preencham os requisitos de admissibilidade e condições de ação para a apreciação pelo STF são exemplos relevantes dessa necessidade. De fato, exigir a apreciação pelos colegiados em todas as hipóteses importaria em inviabilizar o funcionamento da Corte, conforme já destacado.

A crítica central deve recair sobre as competências do Tribunal como um todo. É inviável para qualquer Corte Suprema poder potencialmente analisar ordinariamente demandas sem a menor repercussão geral.Nesse ponto, o Supremo Tribunal Federal provavelmente é um dos recordistas em demandas apreciadas e julgadas em todo o mundo ${ }^{72}$. Ao revés, às Cortes Supremas devem ser atribuídas apenas competências relativas à análise das questões mais relevantes para um determinado Estado e seu ordenamento jurídico.

Portanto, o que se propõe no presente trabalho, por tudo o que foi analisado, é que o marco temporal de 30 anos da Constituição Federal represente um momento de reflexão sobre a necessidade de uma grande reforma constitucional a ser realizada sobre as competências no Judiciário brasileiro. Importante que nesse mister o próprio STF, na posição de órgão de cúpula do Poder Judiciário, inicie as discussões sobre tais reformas e em um primeiro momento dialogue com demais órgãos do próprio Judiciário. Em um segundo momento, é imperioso que o STF se articule junto à sociedade - para fins de accountability social - e aos demais Poderes da República para que uma reforma Constitucional de fato ocorra.

O modelo que este trabalho considera ideal seria o de transformar o Supremo Tribunal Federal em uma Corte Constitucional. Nesse aspecto, a mais alta Corte do país poderia cumprir efetivamente e com efetividade o papel de Guardião da Constituição. Assim, seriam preservadas as competências de julgamento de todas as ações tipicamente de controle abstrato e concentrado, além de competências atinentes ao controle difuso, que incluiria o julgamento de Recursos Extraordinários, nos moldes atuais. É importante destacar ser muito importante que o Supremo Tribunal Federal continue a exercerum criterioso crivo sobre o reconhecimento de repercussões gerais em sede de Recursos Extraordinários, ainda que apenas isso não baste. Em verdade, o Tribunal não caminhará para a viabilidade de uma prestação jurisdicional célere, eficiente e justa caso conheça mais repercussões gerais em um ano do que a sua capacidade de julgá-las ${ }^{73}$. Ademais, é essencial que o Supremo mantenha a competência para o julgamento de reclamações, o que possibilita a manutenção da autoridade de sua jurisprudência em sede de controle abstrato.

No entanto, é relevante se afirmar que o modelo considerado ideal por este trabalho talvez não seja o mais adequado para a realidade política brasileira e nem mesmo para o modelo de Estado adotado no Brasil. É essencial para o bom funcionamento das instituições e da democracia que o STF preserve competências que possam ter repercussões políticas notáveis para o Estado brasileiro. Assim, parece relevante que o Supremo resguarde competências atinentes à resolução de conflitos federativos e de conflitos que envolvam os interesses da Magistratura como um todo ou da maior parte dos membros de um determinado Tribunal. Em segundo lugar, como órgão de cúpula do Judiciário é significativamente importante que mantenha a competência de julgar ações constitucionais que digam respeito a atos ou requerimentos dos Chefes (e tão somente deles) dos demais Poderes e também de ações penais contra os mesmos. Em terceiro lugar, devem ser mantidas ações contra atos ou que julguem crimes dos próprios ministros do Supremo Tribunal Federal. Nesse ponto, seria absolutamente ilógico que os atos dos Ministros da Corte se submetessem ao crivo de juízes, desembargadores ou Ministros de outros tribunais. Em

\footnotetext{
${ }^{72}$ De acordo com o relatório do Supremo em números, de 1990 a 2013 o STF julgou 1.348 .750 processos. Para uma análise minuciosa a respeito do tempo de trâmite processual na Corte v.: FALCÃO, Joaquim; HARTMANN, Ivan A.; CHAVES, Vitor P.. III Relatório Supremo em Números : o Supremo e o tempo. - Rio de Janeiro : Escola de Direito do Rio de Janeiro da Fundação Getulio Vargas, 2014.

${ }^{73}$ Essa foi a proposta de Luís Roberto Barroso ao ingressar como Ministro no STF, posição que reafirmou algumas vezes desde então. Sobre esse tema e também a respeito de outras propostas para aprimorar o sistema da repercussão geral ver: <http://www.migalhas.com.br/dePeso/16,MI274826,31047Como+salvar+a+repercussao+geralIdeias+simples+para+reverter+um>. Acesso em 15.06.2018.
}

Revista de Direito Brasileira | Florianópolis, SC | v. 23 | n. 9 | p. 147-171 |Mai./Ago. 2019 
quarto lugar, este trabalho considera relevante que o STF mantenha a competência de julgamento de Mandados de Segurança propostos por parlamentares por ocasião de vícios no processo legislativo. Mais do que um direito subjetivo do parlamentar ao devido processo legislativo, tratase de uma participação imprescindível do Supremo no sistema democrático, visto que, por exigências do constitucionalismo, uma Suprema Corte deve zelar não somente pelos direitos fundamentais, mas pela preservação das próprias regras do jogo democrático. E não é incomum que, em contextos de crise ou de polarização, as maiorias eventuais queiram aprovar suas preferências políticas no atropelo das regras do jogodemocrático ou dos direitos fundamentais.

\section{CONCLUSÃO}

O presente trabalho se ocupou da análise de dois fenômenos distintos, que possuíram repercussões práticas notórias ao longo dos 30 anos de vigência da Constituição Federal de 1988. Tais fenômenos, se compreendidos e adotados de forma acrítica, podem ocasionar efeitos significativamente negativos. Por exemplo, caso a supremacia judicial e o exercício exacerbado de competências monocráticas pela Suprema Corte sejam apreendidos em conjunto, as clássicas críticas à jurisdição constitucional, como o estabelecimento de um governo de juízes ou da dificuldade contramajoritária, passam a fazer sentido.

Em primeiro lugar, procurou-se demonstrar que, ainda que fosse desejável, nem sempre o Judiciário terá a capacidade de proferir a última palavra, como de fato a realidade brasileira vem evidenciando. Nesse aspecto, é recomendável, pelo menos em algumas searas, a adoção de um modelo decisório que prese por fórmulas dialógicas. Permite-se, assim, a busca por ações concertadas, que ofereçam a possibilidade de se alcançar melhores resultados concretos e que reduzam os riscos de crises institucionais.

Em segundo lugar, foramdemonstrados os problemas práticos do exercício exacerbado de competências monocráticas. O manejo a tal recurso certamente está associado às competências superlativas que são atribuídas pela Constituição Federal e pela legislação infraconstitucional ao STF. Como demonstrado, há riscos democráticos e institucionais eefeitos negativos sobre os jurisdicionados, sobretudo em termos de segurança jurídica. Todavia,demonstrou-se não ser desejável e nem viável a extinção do exercício monocrático de competências. Apenas realçou-se que os riscos e efeitos negativos apontados tendem a ser reduzidos a partir do momento em que se instaurem as necessárias reformas sobre as competências da Corte. Nesse sentido, um dos principais escopos desse rearranjo deve ser o de possibilitar que o funcionamento da Corte seja em uma maior proporção deliberativo.

Em momentos de graves crises institucionais e políticas é preciso que o STF e os seus Ministros fortaleçam a atuação da Corte como verdadeira instituição. Nesse ponto, a preservação do regime democrático e do constitucionalismo impende em diálogos: seja o interinstitucional, com os demais Poderes, seja o "intrainstitucional", através de um modelo deliberativo de decisão.

\section{REFERÊNCIAS BIBLIOGRÁFICAS}

ACKERMAN, Bruce A..The Failure of the founding fathers - Jefferson, Marshall and the rise of the presidential democracy. Cambridge, Massachusetts: Harvard University Press, 2005.

AVRITZER, Leonardo. Impasses da democracia no Brasil. - $3^{\text {a }}$ ed. - Rio de Janeiro: Civilização Brasileira, 2016.

BARCELLOS, Ana Paula de.Sanitation rights, public law litigation, and inequality: a case study from Brazil. In: Health and human rights journal, number 2, volume 16, 2014. 
BARROSO, Luís Roberto.A razão sem voto: o Supremo Tribunal Federal e o governo da maioria. In: Revista Brasileira de Políticas Públicas, Brasília, v. 5, Número Especial, 2015, p. 2350 .

O novo direito constitucional brasileiro: contribuições para a construção teórica e prática da jurisdição constitucional no Brasil. - 3. Reimpressão. - Belo Horizonte: Fórum, 2014.

Curso de Direito Constitucional Contemporâneo: Os conceitos fundamentais e a construção de um novo modelo. - 6 ed. - São Paulo: Saraiva, 2017.

BERGALLO, Paola. La causa Mendoza: uma experiência de judicialización cooperativa sobre derecho a la salud. In: GARGARELLA, Roberto. Por uma justicia constitucional dialógica: el Poder Judicial como promotor de la deliberación democrática. Buenos Aires: Siglo Veitiuno Editores, 2014.

BICKEL, Alexander M. The least dangerous branch: The Supreme Court at the bar of Politics. Second Edition. New Haven and London: Yale University Press, 1986.

BRANDÃO, Rodrigo. Supremacia judicial versus diálogos constitucionais: a quem cabe a última palavra sobre o sentido da Constituição?. - Rio de Janeiro: Lumen Juris, 2017.

.A judicialização da política: teorias, condições e o caso brasileiro. In: RDA - revista de Direito Administrativo, Rio de Janeiro, v. 263, p. 175-220, maio/ago. 2013.

. O outro lado de Marbury V. Madison. In:<http://www.osconstitucionalistas.com.br/ooutro-lado-de-marbury-v-madison>. Acesso em 10.10.2017.

FALCÃO, Joaquim; HARTMANN, Ivan A.; CHAVES, Vitor P.. III Relatório Supremo em Números : o Supremo e o tempo. - Rio de Janeiro : Escola de Direito do Rio de Janeiro da Fundação Getulio Vargas, 2014.

2015.

O Supremo. - 1.ed. - Rio de Janeiro: Edições de janeiro, Fundação Getúlio Vargas,

FISHER, Louis. Constitutional dialogues - Interpretation as a politic process. Oxford: Princeton University Press, 1988.

FRIEDMAN, Barry. The will of the people, how public opinion has influenced the supreme court and shaped the meaning of the constitution. New York: Farrar, Straus and Giroux, 2009.

.The politics of judicial review. Texas Law Review, v. 84, n.2, 2005.

GARAVITO, César Rodriguez. El activism dialógico y el impacto de los fallos sobre derechos sociales. In: GARGARELLA, Roberto. Por uma justicia constitucional dialógica: el Poder Judicial como promotor de la deliberación democrática. Buenos Aires: Siglo Veitiuno Editores, 2014.

GLOPPEN, Siri et all. Courts and Power in Latin America and Africa. New York: Palgrave Macmillan, 2010.

GRIMM, Dieter. Constituição e Política. - Tradutor: Geraldo de Carvalho. Belo Horizonte: Del Rey, 2006.

HAMILTON, Alexander; MADISON, James; JAY, John. The Federalist papers. Mineola, Nova Iorque; Dover thrift editions, 2014. 
HARTMANN, Ivar Alberto Martins; FERREIRA, Lívia da Silva Ferreira. "Ao Relator, Tudo: O Impacto Do Aumento Do Poder Do Ministro Relator No Supremo." Revista Opinião Jurídica (Fortaleza) 13, no. 17, 2015.

HOGG, Peter W.; BUSHELL, Alisson A.. El diálogo de la Carta entre los Tribunales y las Legislaturas (o quizá la Carta de Derechos no sea algo tan malo depués de todo). In: GARGARELLA, Roberto. Por uma justicia constitucional dialógica: el Poder Judicial como promotor de la deliberación democrática. Buenos Aires: Siglo Veitiuno Editores, 2014.

MARSHALL, Willian P.. Conservatives and the seven sins of judicial activism. In: University of Colorado Law Review, v. 73, 2002.

MELLO, Patrícia Perrone Campos. Nos bastidores do Supremo Tribunal Federal. - Rio de Janeiro: Forense, 2015.

MENDES, Conrado Hübner. Constitucional Courts and deliberative democracy. New York, Oxford University Press, 2013.

NOVELINO, Marcelo. O STF e a Opinião Pública. In: SARMENTO, Daniel. Jurisdição Constitucional e política. Rio de Janeiro: Forense, 2015.

PEREIRA, Jane Reis. Representação democrática do Judiciário: reflexões preliminares sobre os riscos e dilemas de uma ideia em ascensão. In: Revista Juris Poiesis vol 17, 2014.

RODRIGUES, Marco Antônio. Manual dos recursos, ação rescisória e reclamação. - 1. ed. - São Paulo: Atlas, 2017.

SARMENTO, Daniel; OSÓRIO, Aline. Uma mistura tóxica: política, dinheiro e o financiamento das eleições. In: 〈http://www.migalhas.com.br/arquivos/2014/1/art20140130-01.pdf〉. Acesso 03.10.2017.

SOUZA NETO, Cláudio Pereira de.; SARMENTO, Daniel. Direito Constitucional: teoria, história e métodos de trabalho. - 2. ed., 3. reimpr. Belo Horizonte: Fórum, 2017.

SOUTO, João Carlos. Suprema Corte dos Estados Unidos - principais decisões. - 2. ed. - São Paulo: Atlas, 2015.

SEGAL, Jefrrey. Judicial Behaviour. In: WHITTINGTON, Keith. The Oxford Handbook of Law and Politics. New York: Oxford University Press, 2008.

SUNSTEIN, Cass R.. A constitution of many minds. Nova Jersey: Princeton University, 2009.

VIEIRA, Oscar Vilhena. Supremocracia. In: Revista direito GV, São Paulo 4(2) | p. 441-464 | jul$\operatorname{dez} 2008$. 